San Jose State University

SJSU ScholarWorks

Master's Theses

Master's Theses and Graduate Research

1992

\title{
The Problem of black access to American higher education is connected to institutional underpreparation
}

Daryl M. Poe

San Jose State University

Follow this and additional works at: https://scholarworks.sjsu.edu/etd_theses

\section{Recommended Citation}

Poe, Daryl M., "The Problem of black access to American higher education is connected to institutional underpreparation" (1992). Master's Theses. 351.

DOI: https://doi.org/10.31979/etd.ucuq-mp7f

https://scholarworks.sjsu.edu/etd_theses/351

This Thesis is brought to you for free and open access by the Master's Theses and Graduate Research at SJSU ScholarWorks. It has been accepted for inclusion in Master's Theses by an authorized administrator of SJSU ScholarWorks. For more information, please contact scholarworks@sjsu.edu. 


\section{INFORMATION TO USERS}

This manuscript has been reproduced from the microfilm master. UMI films the text directly from the original or copy submitted. Thus, some thesis and dissertation copies are in typewriter face, while others may be from any type of computer printer.

The quality of this reproduction is dependent upon the quality of the copy submitted. Broken or indistinct print, colored or poor quality illustrations and photographs, print bleedthrough, substandard margins, and improper alignment can adversely affect reproduction.

In the unlikely event that the author did not send UMI a complete manuscript and there are missing pages, these will be noted. Also, if unauthorized copyright material had to be removed, a note will indicate the deletion.

Oversize materials (e.g., maps, drawings, charts) are reproduced by sectioning the original, beginning at the upper left-hand corner and continuing from left to right in equal sections with small overlaps. Each original is also photographed in one exposure and is included in reduced form at the back of the book.

Photographs included in the original manuscript have been reproduced xerographically in this copy. Higher quality $6 "$ " 9 9" black and white photographic prints are available for any photographs or illustrations appearing in this copy for an additional charge. Contact UMI directly to order.

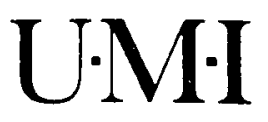

University Microfilms internatıonal

A Bell \& Howell Information Company 300 North Zeeb Road. Ann Arbor. MI 48106-1346 USA

313:761-4700 800:521-0600 
-

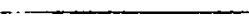


Order Number 1348712

The problem of Black access to American higher education is connected to institutional underpreparation

Poe, Daryl Monroe, M.A.

San Jose State University, 1992

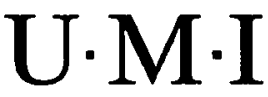

300 N. Zeeb Rd.

Ann Arbor, MI 48106 


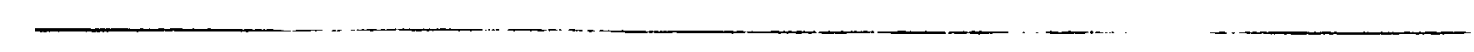


THE PROBLEM OF BLACK ACCESS TO

\title{
AMERICAN HIGHER EDUCATION IS CONNECTED TO
}

INSTITUTIONAL UNDERPREPARATION

\author{
A Thesis
}

Presented to

The Faculty of the Department of Social Sciences

San Jose State University

\author{
In Partial Fulfillment \\ of the Requirements for the Degree \\ Master of Arts
}

By

Daryl M. Poe

May, 1992 
APPROVED FOR THE DEPARTMENT OF SOCIAL SCIENCES

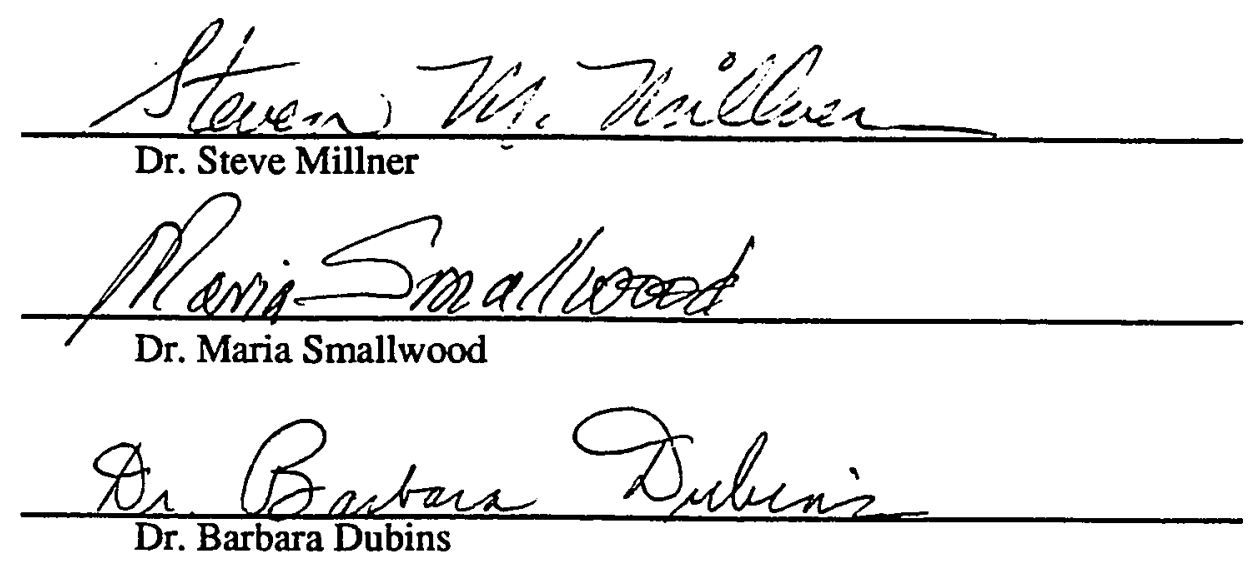

APPROVED FOR THE UNIVERSITY

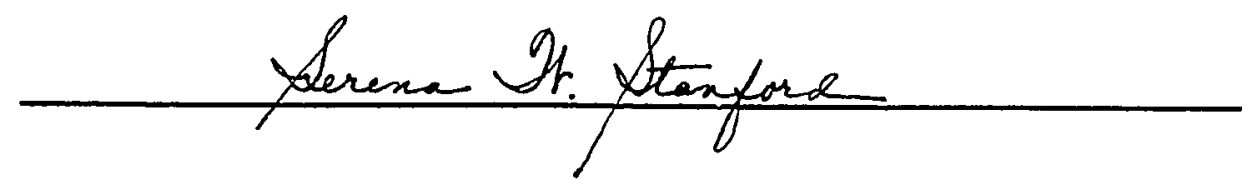




\title{
ABSTRACT \\ THE PROBLEM OF BLACK ACCESS TO AMERICAN HIGHER EDUCATION IS CONNECTED TO INSTITUTIONAL UNDERPREPARATION
}

\author{
by Daryl M. Poe
}

This thesis examines the impact of institutional underpreparation on Black access to American higher education. It reviews the literature on declining enrollment of Black students in American higher education and assesses the roles of socioeconomic factors, lingering institutional racism, Black high school student ineligibility, and curricular deficiencies. Additionally, recommendations from the sources reviewed are studied.

Research reveals that the attitudes formed during the American Slavery and postReconstruction eras, have limited the ability of historically White colleges and universities to attract Black undergraduates. This study shows that the majority of American institutions of higher education are culturally inconsistent with the Black cultural experience. This inconsistency is perceived by the University of California as a problem of ineligibility on the part of Black high school graduates. The lack of preparation and shortsightedness of the University of California system as representative of historically White colleges and universities is revealed through a close examination of recruitment strategies. 


\section{REVIEW OF THE LITERATURE}

From 1980 to 1987, the number of Black students attending college dropped significantly with Black males accounting for only 3.5 percent of the national college enrollment (Task Force on Black Student Eligibility, 1990, p. 4). There are many publications available that offer reasons for this situation. This chapter is an overview of some of the most comprehensive literature on the topic.

\section{Declining Enrollment of Black Students in Colleges and Universities}

According to Sudarkasa (1988), there was a reversal in the success experienced by Blacks in U.S.A. higher education. He stated that, "Blacks were the only major racial or ethnic group whose undergraduate enrollments declined between 1980 and 1984; other minorities and whites experienced an increase" (p. 8). He wrote that this trend was also true of graduate school enrollments.

The reasons behind this enrollment decline, according to Sudarkasa (1988), were "the reduction and redirection of financial aid dollars; cutbacks in federal funding for precollege outreach and academic support programs; the rising costs of a college education; and the erosion of the earning power and income of black families as a result of back-toback recessions" (p. 11). He stated that the rising cost of higher education enhanced the attractiveness of military service as a stepping-stone to success.

In an enrollment comparison between Black campuses and White campuses, Sudarkasa (1988) found that between 1976 and 1980, Black enrollment at Black colleges remained stable while Black enrollment at White colleges dropped steadily. $\mathrm{He}$ attributed the decline in the White colleges to the poor experience that Blacks had, as reflected in: (1) limited participation in extracurricular activities outside of sports, (2) 
limited access to leadership roles, (3) limited choice of academic concentrations, (4) relative absence of faculty mentoring, and (5) limited academic success measured by graduation rates.

Lang (1988) viewed the Black decline in success in higher education as a crisis. Lang observed a that enrollment of Black students in college decreased by 40,000 between 1976 and 1984, though high school completion rates and numbers increased during that same period. Lang found a prominent cause of this failure was attributed to the scattering effect of rushed school integration which had the effect of diminishing the presence of Blacks as role models in responsible positions and mentors. Lang stated that in 1983 , out of 43,000 public school administrators in the country, only 3,000 were Black; out of 96,000 public school principals and assistant principals, only 11,000 were Black; and out of 1,887,000 public school teachers, only 192,000 were Black, which was down from 199,000 in 1974 (p. 7). Lang also showed that Blacks were underrepresented in 56 of the 65 flagship universities (p. 8).

Lang (1988) made the point that Black colleges remained more successful with retention of Black students than predominantly White colleges in the area of graduation despite of the fact that predominantly White colleges were more selective in the students they admitted (Lang). While Black and urban institutions accounted for the majority of the bachelor degrees awarded to Black students, the future of these institutions was unstable due to changed economic and political climates, and competitive incentives that drove faculty to move to predominantly White colleges and universities.

According to Lang (1988), attrition rates of Black students were attributed to Black students' socioeconomic background and the peculiar characteristics of higher education institutions in America. Lang asserted that the problems of Black "student retention and attrition cannot be divorced from their sociocultural, socioeconomic, and family backgrounds, or the ramifications of the larger society that perpetuates these 
characteristics" (p. 9). In Lang's opinion, the educational and political systems opted to blame Black students and their socioeconomic backgrounds for academic situations beyond the control of Black students.

\section{The Factor of Socioeconomic Status}

"To understand the overt, and later covert, forms of discrimination and racism practiced in higher education as public policy, one must understand the history of American society and the black experience within that larger history. With the exception of the American Indians, no other group in American history has been so consistently and systematically discriminated against and denied its basic human rights" (Flemming, Gill, \& Swinton, 1978, pp. 14-15). Slavery, the basis of socioeconomic relations between races in the South prior to the Civil War, negatively impacted relations between Whites and Blacks in the not-so-distant North. Slave codes prohibited Blacks from leaming to read and write and therefore assigned Blacks to the bottom position of a caste system. While free Blacks, with their meager resources, allied with abolitionists to organize Black schools, the majority of Blacks in America went without education (Flemming, Gill, \& Swinton).

There was also a short period of reprieve for Blacks known as the "Reconstruction Period" which immediately followed the Civil War. However, this decade of progress was followed by the retrogressive era of "separate but equal" (Plessy v. Ferguson, 1896) issuing in official segregation. According to Flemming, Gill, and Swinton (1978), this atmosphere of extreme racism worked against the placement of the small number of Black scholars at institutions of higher education. Flemming, Gill, and Swinton asserted that there has been a long record of exclusion of Blacks from education in general and higher education in particular in the United States of America. 
Convincing data supported the fact that Blacks with higher degrees had higher incomes than those without (Institute for the Study of Educational Policy [ISEP], 1976). Freeman (1976) displayed the direct connection between: (1) educational opportunity provided in the late 1960 s and the 1970 s by anti-discrimination laws, and (2) diverse equal employment measures accompanying the Civil Rights Act of 1964, and their impact on the rise of a "Black Elite" (a term referring to a group of relatively high income Blacks with college education). Interestingly, Freeman pointed out that the gains this group made were accompanied by the development of increased stratification in the socioeconomic situation of Blacks in America. He pointed out that it was the children of the better educated and wealthier parents that actually increased Black enrollment in the colleges rather than the ghetto poor.

It has been reported that the economic burden of a college education is heavier for lower income minority populations than others (Task Force on Assembly Concurrent Resolution 83 [TFACR83], 1986). Drop-out rates for students attending schools in which the population was predominantly minority were disproportionately high, and minority admissibility to the University of California and the California State University was disproportionately low. Without major improvements in this situation, California's economy, society, and culture will suffer (TFACR83). In "1988 more than one in five African Americans in California were living below the poverty line, the majority concentrated in urban school districts with relatively poor resources... The social and economic circumstances responsible for this situation are hardly improving" (Task Force on Black Student Eligibility, 1990, pp. 4 - 5). Blacks, on the average, came from relatively depressed socio-economic backgrounds; thus, they tended to be underprepared academically when they entered colleges or universities (Anderson, 1989). Anderson stressed that this problem negatively impacted retention and success rates. He went on to 
state that the problem had become a major concern of predominantly White universities and colleges because: (1) they needed to meet federal guidelines for funding support, and (2) they needed to fill vacancies left by the decline of the "Baby Boomer" generation.

\section{The Role of Racism}

The Carnegie Council on Policy Studies in Higher Education sponsored, in its report titled Selective Admissions in Higher Education, an essay by Winton H. Manning on the pursuit of fairness in admissions to higher education (1977). The important vanguard research of the Carnegie Council was seen as vital to policy formation on many campuses. In his essay, Manning addressed important questions facing universities on the issues of fair admissions.

Manning (1977) tackled the question of whether minority status should be an explicit criterion in the admission of students into higher education from an educational vantage point versus the strict legal sense. He posed the question of group versus individual equity. While Manning focused on graduate level admissions, he showed how sponsored admissions versus the contest process of individual competitors led to the Bakke case. While accepting the need for minimal competency, Manning asserted that race was a relevant criterion when considering ways to construct a pipeline in higher education for a group that had been historically denied access. He stated that other factors such as geographic distributions, career aspirations, and gender should be considered to balance out the educational experience of a given class.

"White universities and institutions of higher learning are microcosms of the larger society" (Dejoie, 1986, p. 229). To Dejoie, this factor could not be ignored if one was to address the problem of equal access in higher education. According to Dejoie, any 
strategy that sought to address the disenfranchisement of Blacks in White universities had to consider the fact that universities are subjected to the same consequences found in society at large, including the moral and social problem of providing equal opportunity and benefits to all of its members. The most popular formal response to this situation has been affirmative action.

Flemming, Gill, and Swinton (1978) stated that the objective of affirmative action was to rectify existing discrimination and remedy the suffering and deprivation of generations of Blacks in the United States of America. Discrimination was part of the campus environment and was supported by the university structure. In this structure faculty hirings were usually done by small, closely knit units that tended to justify hiring choices with vague and subjective criteria. Sometimes the hiring criteria were designed to block the access of potential minority candidates. Thus, the need for affirmative action was clear.

Flemming, Gill, and Swinton (1978) went on to show the excuses used by the institutions of higher education for not admitting Black faculty, staff, administrators, and students and the battle to force access through a long list of legal cases.

A case study analysis of Florida State University's Affirmative Action plans and implementation done by Flemming, Gill, and Swinton (1978) revealed attitudes detrimental to achieving affirmative action.

On the issue of the university hiring less qualified blacks and women, one dean suggested that she did not think that even the white males who raised the issue believed that the university was hiring unqualified faculty members. The university attorney suggested that it was difficult for members of the faculty to stop using the traditional method of hiring in favor of a more fair method. Further, it was difficult for them to acknowledge that women and minorities are as qualified as males and, in some professions, even more qualified. Blacks, for example, can play a very important role in a predominantly white university in exposing white, middle-class students to minorities and to those with different cultural backgrounds. 
He emphasized that qualifications are defined by white males and are not necessarily the best criteria just because they happen to fit their own academic interest. ...

At [Florida State University] there was only one tenured black on the faculty. One official indicated that the explanations given to justify the lack of black faculty are often simply excuses. ... One provost suggested that the issue of merit is raised primarily in relation to blacks and women. The merit principle is often used to eliminate nonwhite males but still allows incompetents to achieve tenure. $\mathrm{He}$ further stated that those objecting to the [affirmative action] plan do not fear incompetent blacks, but rather fear competition with competent blacks using the same standards of merit. (pp. 154-155)

The problem of unmonitored policies for equal access was also surveyed in their work. The successful impact of those policies that had enforcement power was highlighted, showing that sincere commitment can actually remove the obstacles plaguing the society and its institutions (Flemming, Gill, \& Swinton, 1978).

Anderson (1988) claimed that it was "fallacious to assume that the opportunity and situations for Blacks are improving and that progress is being made toward real equal opportunity and access" (p. 270). Anderson asserted that while racism may be seen as an abstract thing, it is nonetheless real and perceivable by the mind and senses and therefore has an impact on the "social climate, political ideology, and economic policy within an educational, governmental, or commercial institution" (p. 259). In relating racism to the general condition facing Black faculty, students and staff at predominantly White universities and colleges, Anderson viewed the situation as a reflection of elitism, ethnocentrism, and egoism manifested on a racial basis.

Anderson (1988) stated that racism increased as a dominant attitude at White universities and colleges once Black students and faculty gained admission and employment. According to Anderson, Blacks focused on education as a means of achieving integration into American society. In Anderson's opinion, White universities resisted the move toward integration because of their historical role of legitimating racial 
stereotypes and "racist-oriented scholarship related to Africans and people of African descent" (Anderson, 1988, p. 263).

Anderson (1988) observed that little had changed since 1862 in regards to Blacks' encounters with racism at predominantly White colleges and universities. What Blacks have encountered on White campuses has been:

(1) a physical environment and social culture alien to their own background and tradition; (2) racially tense or strained relationships with whites due to conflicting lifestyles, interests, and activities; (3) apprehension and uneasiness on the part of white faculty, and a common attitude that Black learning capabilities are marginal, especially in the quantitative and technical fields. White faculty, being products of a racist society, still find it difficult to adjust to Black faces in their classrooms. (4) Textbooks that reflect the ethnocentric and racist ideologies of white dominance and cultural supremacy still reign supreme. The history, life, and culture of 30 million Black Americans are still virtually ignored in adopted textbooks. (5) There continues to be ostracism by white students and faculty based on racist perceptions. (p. 264)

These situations are the direct result of White elitism and ethnocentrism prevalent in the traditional academy (Anderson, 1988). According to Anderson's study, anyone that was culturally and radically different is considered inferior. Anderson states that these were some of the reasons that Black students form their own student associations, cafeteria areas, etc.

With a few exceptions, most Black faculty and administrators have been employed within White academe as a result of the demands from matriculating Black students (Anderson, 1988). Anderson pointed out that the "line-authority positions" given to Blacks were usually the result of recruiting Blacks who articulated a distaste for anything specifically Black, such as Black Studies and Black Programs, as efforts to segregate Black students. These administrators were then assigned to assist with the dismantling of these programs (Anderson). 
Few white institutions publicly claimed to be racist but they advocated racist strategies and couched them in terms of "quality," "excellence," and "qualifications" based on subjective, elitist, and ethnocentric parameters (Anderson, 1988).

In Allen's (1988) study, his conclusions lead to the overall assessment that the experience for Black students at predominantly White campuses was a negative one. Allen found that while the students he served did reasonably well academically, their college grade point averages were lower than the grade point averages of the general population at the colleges they attended and lower than their own previous high school grade point averages. In Allen's opinion, the high schools which educated the students did not provide preparation in two important areas: academic advancement and social utility. Allen stated that socially, this was the first time that many of the students became a "minority." According to Allen's research, 79\% (p. 63) of the students surveyed believed that there was an inadequate number of Black students on their campuses. Black student contact with Black faculty was also found to be low according to Allen's study.

While feeling able to communicate with White peers on a one-to-one level, Black students felt that racial tensions between groups were high (Allen, 1988). According to Allen's study, $60 \%$ (p. 65) of the students surveyed described experiencing at least one incident of racial discrimination. Allen pointed out that $76 \%$ (p. 65) of the Black students reported that White faculty had problems relating to them.

Allen (1988) stated that a substandard program of K-12 education had given rise to continuing educational disadvantages, lower test scores and grades, and more limited occupational goals among Black college students than White students. He stated that this also lessened the likelihood of these students pursuing postgraduate studies, thus sabotaging the "pipeline." He went on to assert that Black students experienced less social and psychological satisfaction than their White peers at predominantly White 
colleges and universities. Allen stated that spiritual deficits experienced by Blacks in their early school years had a more devastating impact than the educational deficiencies because they lowered the students' self-confidence, motivation, and understanding of education's transformational power. In spite of all these negative factors some students succeeded due to talent, persistence, and self-confidence (Allen).

American schools mirrored society's view that Blacks are ultimately uneducable (Allen, 1988). According to Allen, the colleges and universities in America inherited the cumulative traditions of the society. In his opinion, the universities and colleges should be held responsible for the dismal situation in contemporary Black higher education. "The teaching mission should require that state universities have to adapt to the realities of serving a diverse citizenry in terms of cultural orientations, economic standing, and academic backgrounds. ... The science and art of teaching has been subordinated to the business of grantsmanship and publication among college faculty" (p. 79). Basically, according to Allen, an academic Social Darwinism was encouraged. Allen asserted that the smug attitude of "college is not for everyone" and its accompanying behavior had resulted in decreased access for Blacks in American universities and colleges.

\section{Black Student Ineligibility as the Problem}

The problem of Black student access to public colleges and universities in California has been seen by university faculty and state legislators as one of underpreparation, thus ineligibility, on the part of Black high school graduates (California Post Secondary Education Commission, 1988; Underwood, 1988). The following is a passage from a report by the University of California's Task Force on Black Student Eligibility (TFOBSE) which sums up the tone of this perceived problem. 
The issue of African American student eligibility is not solely the problem of African Americans, nor is this a matter that can be adequately addressed at the margins of the academy. Rather, it is a problem that is symptomatic of the crisis in American educational institutions. As such, it should not be regarded as a problem that can be addressed with "special programs" in some corner of the campus. Instead, it is an institutional problem which should be at the core of the University's mission... The University can do a better job of tapping into community strengths, and supporting (without dominating) community-based academic achievement programs. (TFOBSE, 1990, p. 8)

While the Black high school completion rate has increased steadily since 1970 , the percentage of Blacks that attended college has declined since 1980 (Underwood, 1988, p. 8). This problem appears to be getting worse considering high school attrition rates for Black students in 1985 were nearly $50 \%$ and $1 / 3$ of the $50 \%$ that did graduate did so with a less than 2.0 grade point average (CPEC, 1985, December, p. 6).

The California Postsecondary Education Commission (CPEC), in 1985, was mandated to do an assessment of the effect of California's Master Plan on California's colleges and universities in response to the 1982-83 Budget Act. The study omitted high school drop-outs which, if included according to age group, would have substantially lowered the eligibility rates of Blacks (34\% high school attrition rate) and Hispanics (36\% high school attrition rate). "In 1982-3, the grade-point average of all [public high school] graduates was 2.62, but for Black graduates it was $2.26-13.7$ percent lower. Twice as many Black students as all students ... graduated with grade-point averages below 2.0: the minimum for State University admission" (p. 46). The report also revealed that Blacks scored the lowest amongst California's major ethnic groups on SAT composite scores, 23.2 percent below statewide averages.

The CPEC (1985) report revealed that of all ethnic groups examined (Native Americans were excluded), Black high school graduates were the least eligible to attend the University of California (UC) and California State University (CSU) according to their high school grade point average (GPA), and second least eligible according to the 
combined GPA and admissions test scores. "While 13.2 percent of all 1982-83 public school graduates met the University of California's eligibility standards, only 3.6 percent of Black graduates did so. And while 29.2 percent of all graduates met the State University's standards, only 10.1 percent of Black graduates met them" (p. 46).

The Black graduates that met the UC admission standards enrolled at a UC campus at a rate higher than the general population. Those Black graduates that met the CSU admission standards also enrolled at a slightly higher rate than the general population (CPEC, 1985).

\section{The Role of Curriculum}

The Carnegie Council on Policy Studies in Higher Education report completed in December, 1977, focused on the role and mission of the undergraduate curriculum and posed recommendations needed to improve it. It gave an overview that breaks the historical periods of the undergraduate curriculum into three distinct phases: (1) 1636 1870, which focused on western civilization, (2) 1870 - 1960, which focused on development of human capital, new knowledge and technology, and (3) 1960 - present, which focused on the maintenance of former perspectives with the addition of consumerism.

The report found that while there was a high level of satisfaction among the faculty and students with the current curriculum, approaches for its improvement were haphazard. "Faculty members pay attention to their individual courses, departments to their majors, and students to their choice of electives; but few persons pay attention to the other three components and to the overall enterprise" (Carnegie Council on Policy Studies in Higher Education [CCPSHE], 1977, p. 133). Their recommendations for 
improvement included the provision for heightened self awareness and "programs and environments that help students cultivate tolerance for ideas that are different from their own" (CCPSHE, 1977, p. 141).

Ferris (1979) stated that the classical curriculum of Eastern colleges had a nineteenth-century heritage with limited relevance to today. It was a curriculum designed to service a small, elite, professional class. The assumption was that the general population was incapable of higher learning. High school education was not common until the end of the nineteenth century and it was predominantly "college preparatory" well into the twentieth century.

Nobles (1989) asserted that culture influenced the development of and was reflected in the content of all curricula. A curriculum was a source of study which sought to guide the transmission of information and knowledge, reinforced the desire for knowledge, and encouraged behavior and attitudes consistent with that knowledge.

Most mainstream American educators and scholars have rendered the relevance of culture to education as, at worst, the "something" which is really irrelevant to the task of education and should be disregarded (i.e., I don't see color, we should just teach children, etc.). At the other end of the cultural chauvinism continuum is the position that some cultures, at best, are deviant and should be replaced, or are deficient and should be strengthened before they can serve or address the educational agenda or curric iitum concerns. In this latter case, the culture of a particular group becomes akin to a specialized subject matter and thereby a feature or a component of the curricula. In this regard, the importance of culture is reflected in the curriculum by it (the curriculum) being sensitive to the ethnic heroes and holidays and aware of the group's songs and dance. Culture is not, however, simply a compilation of ethnic heroes and holidays nor is it only an awareness of other people's music and dance. (p. 5)

According to Nobles, culture's influence on curriculum concerns in American education has been elusive and evasive. Nobles (1989) went on to state that, "cultural domination in the guise of acculturation and assimilation has been the modus operandi for American education and curriculum development" (p. 6). 
Nobles defined culture as, "the vast structure of behaviors, ideas, attitudes, values, habits, beliefs, customs, language, rituals, ceremonies and practices peculiar to a particular group of people which provides them with a general design for living and patterns for interpreting reality" (p. 6). He asserted, therefore, that culture is as significant to peoples as water is to fish. His analogy was used to assert that cultural specificity is crucial to understanding the specific requirements for the development of each people (i.e., salt water fish need salt water vs. fresh water fish need fresh water). In Nobles' opinion, education is a human invention and is therefore steeped in a particular culture. "In fact, all of our training and education are bound by what we call customs or professional conventions, which are nothing more than cultural traits or rituals" (p. 6). Nobles explained this further in the following passage.

The fact of the matter is that when we look at the notion of culture and raise the question of accessing children to a core curriculum, we should be very clear that the core curriculum itself is cultural; and that the teaching methodology that we utilize in teaching the core curriculum is also cultural; and that the site leadership style is cultural, and that the instructional strategies are cultural, and that the school climate is cultural, and that ultimately the aim and purpose of education itself is cultural.

In fact, if we understand the issue of culture, we should see that it is not a "social product" (i.e., something we can add on to what we are doing) and that culture is really the total human process. As the everything of human reality, culture in education becomes how we use the "spirit and the energy" of a people. (p. 9)

In addressing what he saw as the necessary infusion of culture in curricula content, Nobles (1989) described in technical language the purpose of curricula. He stated that the purpose is to "(1) systematically guide the transmission of information and knowledge, (2) reinforce the desire to learn/know, and (3) encourage the internalization of behavior and/or attitudes consistent with the knowledge learned" (pp. 9-10). A significant amount of this study was dedicated to providing a model curricula reflecting African, or Black, cultural specific infusions in both content and intent. 
Nobles (1989) asserted that there is a relationship between the presence of Black, or African, culture in the curriculum and Black student achievement. In his opinion, the infusion of culture in the content and intent of the curriculum requires culturally consistent educational practice:

Culturally consistent educational practice is designed to allow our children to:

(1) achieve mastery of all aspects of human functions,

(2) to reproduce themselves in the objective world; and,

(3) to make explicit their character/personality. (p. 18)

\section{White Colleges and Universities Lack Necessary Preparation to}

\section{Serve the Black Population}

"The land-grant colleges and the state educational institutions of post secondary learning were the first unique contribution of America to the picture of higher education in the western world" (Ferris, 1979, pp. 87 - 88). The second major impact came with influx of World War II veterans due to the G.I. Bill. The results of this impact was: temporary reduction of recruitment and an increase of older students on the campus. Neither the admissions criteria, curricula, nor academic standards changed for this new cohort of entering students. The next major group to be introduced into the White academies presented profound challenges because of the heterogeneity they brought to a relatively homogeneous environment (Ferris).

This new group, which gained access to White academies in the wake of the Civil Rights struggles of the $1960 \mathrm{~s}$, included "students marked by a diversity of language background, cultural background, educational preparation, role-goal aspirations, life styles, learning styles, stages in life cycle, and ranges of expectations" (Ferris, 1979, p. 89). Special opportunity programs sponsored specially admitted students who were deemed either educationally disadvantaged or had a history of economic disadvantage. 
The major problems faced by these special admits and their sponsoring programs were (1) resistance to change endemic to the educational institutions, (2) shrinking financial support for institutions of higher learning, (3) lack of preparation of the academy to serve this diverse group, (4) hostility of academic elitism and institutional racism, and (5) the curricular and pedagogical rigidity of the faculty (Ferris, 1979).

The introduction of this new and diverse group to the State University of New York system gave rise to: (1) the inception and expansion of programs and departments in ethnic minority studies and women studies, (2) expansion of career planning, tutorial, and life style services, (3) creation of pass/fail grading options and independent studies, (4) the inception or expansion of summer pre-college programs for students with remedial needs, and (5) an increase in vocational and professional oriented courses and programs (Ferris, 1979).

The problems of heterogeneity of the populace in institutions of higher learning is a multifaceted one that is ultimately, but not easily, solvable. It will require the full physical, financial and educational resources of the institutions.

Thus, it is not enough to specially admit students and get them ready for the college: the instructional staff, and the college programmes must be gotten ready for the students. (p. 96)

This is a scholar whose description of the area of retention and academic success is comprehensive. Anderson (1989) pointed out that predominantly White colleges and universities tend to organize their retention strategy on two fronts: (1) counseling programs and (2) academic programs. He criticized such academic programs because they focus narrowly on remediation and fail to go effectively beyond that. He stated that counseling programs are more numerous than the academic programs because retention programs are normally started by student services wings of the campus rather than by academic wings. Nevertheless, most of these programs failed because they were built on the false assumptions that retention and success required that the incoming students 
should have been molded to fit in by the retention programs. This was to happen regardless of students' cultural backgrounds.

These programs were usually locked into Anglo-European values and notions about cognitive functioning, learning and achievement while at the same time invalidating the values and notions of minority populations. When differences were recognized by those who managed these programs, they were oversimplified and lumped into sweeping racial categorizations. The understanding of cultural differences and their subcategories was seen as standard (White) versus non-standard (minority). In this environment it did not take long for the student from a minority culture to see that the institution, regardless of its literature, did not support a multicultural reality. The success of these minority students was directly related to their acceptance of the dominant culture (Anderson, 1989).

Anderson (1989) asserted that all components of a culture are constructed upon basic conceptional systems or philosophical world views. While the various cultures may address similar phenomena, their perspectives and responses vary. Thus, different cultures produce different learning styles, which themselves call for variation in cognitive behavior. Here Anderson asserted that a significant number of African behaviors, values and beliefs remain among Blacks in the United States which he specifically attributed to the Black church and family. While he agreed that some behaviors were borrowed from the dominant culture, Blacks' cultural style sufficiently prevents total assimilation.

According to both Anderson (1989) and Mbiti (1970), a focus on unity and connection is the most characteristic feature of African philosophy. According to these scholars, African philosophy is centered around a view of extraordinary harmony in which persons and peoples are rhythmically united with nature and the cosmos. This philosophy gives rise to logical canons which assert the interdependence of humanity with the community, nature, and the universe. 
This view is often at odds with the abstractedness of the dominant Western or European philosophy. This philosophy is reflected in cultural styles and classroom learning. The typical classroom in an American university operates in a cultural style attuned to Whites. Studies on this issue show that White children scored higher than nonWhites in individualist motivated tests. Whites also scored higher in tests that do not require that they be bicultural, bidialectic or bicognitive. All other groups are unfairly required to have this skill in order to succeed (Anderson, 1989).

Through a contrast of cognitive styles, worldviews and linguistic styles, Anderson showed the impact of these differences on the success, or lack thereof, of Blacks in the educational system. Finally, Anderson (1989) suggested that a different set of understandings regarding how diverse populations communicate, behave and think needs to be developed by educators.

In a similar analysis, Stikes (1984), through a review of relevant literature combined with case studies, advanced a comprehensive method for assisting Black students in their struggle for success at predominantly White campuses. Stikes took a developmental approach to the assessment of the needs of the student coming from the Black community and showed how this experience came into conflict with the approaches and coping strategies used in predominantly White colleges. The values and coping strategies of the White universities appeared to contradict the values and coping strategies of the Black students.

Stikes (1984) generally asserted that while Black students can succeed in predominantly White universities, that success was in spite of what those universities do. He suggested that if these institutions wanted to improve their success rates among their Black population, they had to examine the coping strategies of both the students that succeeded and those that chose to leave the institution before successful completion. Stikes stressed the need to see the counseling of Black students as a holistic process that 
takes into account the socioeconomic background of the individual students and the communication customs common to the Black community. Without proper communication links built up between the administration and faculty and the Black student population, stressful intercultural relations create obstacles to Black students' success.

Ethos tends to be affected by lifestyle and socioeconomic status of those that run the colleges and universities (Smith, 1974). Smith presented a revealing analysis of the impact that the wealthy have had on higher education in America. He asserted that the primary role of the American university system was to serve as a discount training process for future employees of big business. In his opinion, decisions of various regents and trustee boards were all impacted by this fundamental goal. Smith also provided a statistical analysis of the socioeconomic make-up of the regents and trustees of major university systems. His expose of the biographies of University of California regents (early 1970s) strongly supported his analysis. The socioeconomic distance between the University of California regents as a group and the Black community weakened the case for academic partnership because both groups have vastly different daily experiences, thus perspectives. Communication between the groups, the basis of understanding, was negatively impacted by both groups' lack of familiarity with each other.

The 1986 report by the Intersegmental Policy Task Force on Assembly Concurrent Resolution (IPTFACR83) had a mission to improve the high school graduation rates of low-income and minority students. According to IPTFACR83 (1986), low-income and minority students must feel that higher education is an open option. IPTFACR83 predicted that without increased cooperation and partnership among the $\mathrm{K}-12$ segments, the improvements would not happen. The report recommended that the implementing agents of clarifying college and university responsibilities be the President of the 
University of California (UC), the Chancellor of the California State University (CSU), the Chancellor of California Community Colleges, and the President of the California Association of Independent Colleges and Universities. It was recommended that the President of the UC system and the Chancellor of the CSU system be included as two of the implementing agents for the following areas: (1) assuring improvement in the public schools, (2) increasing higher education's services to the schools, (3) reassessing outreach and other school services, (4) including multicultural emphasis in teacher education, (5) recruiting minority students into the teaching profession, and (6) undertaking action research on school problems (IPTFACR83, 1986).

In the area of higher education's services to underrepresented students, it was recommended that the President of the UC system and the Chancellor of the CSU system implement the tasks of: (1) getting outreach and admissions staff to view potential students as potential graduates, (2) expanding orientation and summer bridge programs, (3) increasing faculty participation in tutorial programs, (4) providing academic and career advising, (5) helping the community colleges with the EOPS transfer process, and (6) expanding the evaluation of their own special support programs (IPTFACR83, 1986).

In the area of higher education's services to elementary and secondary schools, it was recommended that the President of UC and Chancellor of CSU accomplishment the tasks of: (1) implementing teacher education programs emphasizing the multicultural aspects of California's school population, and (2) implementing research that illuminates those environments that are most conducive to promoting minority success in higher education. Another suggestion was made that the UC system and the CSU system representatives should simplify the performance reports they send to high schools and community colleges about their former students (IPTFACR83, 1986). 
While there were suggestions for K-12 faculty to increase their provision of multicultural education, there was no similar recommendation made for the faculty at the UC system or the CSU system (IPTFACR83, 1986).

Sudarkasa (1988) recommended that: (1) the higher education community take responsibility for changes in the K-12 system to improve the enrollment of Blacks in higher education and, (2) the curriculum and faculty have a larger Black and minority infusion. Sudarkasa stated that the issues of diversified faculty and multicultural curriculum must not be seen in the limited terms of affirmative action but should be seen as enhancing the scope and function of higher education.

Lang (1988) recommended that institutions "finally recognize that in their peculiar ways, black and white students are inherently different; they come from different backgrounds with different orientations, ideologies, perspectives, and with different perceptions of success and failure" (p. 10). Only with this recognition could predominantly White colleges begin to realize success with Black students.

The following recommendations were suggested as being necessary by Allen (1988):

(1) University commitment to increasing Black presence must be clearly communicated throughout the university with rewards and sanctions for departments, faculty and staff that comply or that fail to comply.

(2) The traditional admissions selection process should be modified to include a broader criteria of student potential.

(3) Support programs facilitating academic, psychological, cultural, and health needs must be developed and coordinated by the universities.

(4) Universities must experiment with different approaches to teaching and learning.

(5) Universities must retool themselves to meet the needs of changing demographics. (p. 80)

Educators need to provide a core curriculum for everyone that allows for different cultural integrities. Curricula content needs to use life experiences, history and traditions of Blacks and other non-Whites as referential points. Curricula should utilize the global 
Black experience "as the core paradigm for human liberation and higher-level human functioning" (Nobles, 1989, p. 21). The curriculum should help Black students to recognize that they can be active agents in changing history.

The major finding of the Task Force on Black Student Eligiblity (TFOBSE) was that one-dimensional, unilateral approaches to the issue of Black student access by single institutions are unavoidably inadequate. The TFOBSE stated that the UC system alone could not resolve this problem, nor was it felt that the UC system should. The TFOBSE urged that a comprehensive effort, including the UC system, the state of California and national organizations, should be made to address the problem of Black student eligibility immediately. Within the UC system, the TFOBSE recommended initiatives involving UC system sponsored precollege programs, community college transfer programs, the UC system's school of education, the recruitment of Black faculty, and the development of a unit to research and disseminate information on the issue of African American achievement (TFOBSE, 1990).

The TFOBSE specifically recommended that the UC system improve the coordination and effectiveness of their various precollege programs for Black students. The TFOBSE also suggested that the UC system provide greater support for existing initiatives and special programs to transfer Black community college students to the UC system, recruit and hire more minority faculty, and ensure UC schools of education increase their multicultural classrooms. Finally, the TFOBSE recommended that the UC system establish a multi-campus research unit focusing on increasing the academic achievement of Black students (TFOBSE, 1990).

In terms of collaborative efforts, the TFOBSE recommended that the UC system take the lead in the development of school-improvement collaborations, create mechanisms to support independent community-based programs and, in collaboration with industry and government, support Black community economic and health services 
development efforts. The TFOBSE also suggested that the UC system work with the State Department of Education, the Commission on Teacher Credentialing and other concerned agencies in advancing a curriculum sensitive to diversity in the K-12 and postsecondary levels. Finally, the TFOBSE recommended that the UC system assist with the sponsorship and promotion of legislation designed to insure financial and academic support for "at-risk" potential Black college and university students (TFOBSE, 1990).

The United States of America is in crisis because it is failing to serve and prepare an increasing number of its Black citizens for tomorrow's exigencies. The socioeconomic nightmare created by this deficiency can negatively affect the future of the nation in many ways.

This chapter reviewed causes of the reversal of increased Black participation in predominantly White colleges and universities. These causes included: (1) socioeconomic factors, (2) institutional racism, (3) ineligibility of Black high school graduates, (4) curricular deficiencies, and (5) a fundamental lack of preparation on the part of colleges and universities. A list of recommendations from the sources reviewed was included. 


\section{HISTORICAL BACKGROUND OF BLACKS \\ IN AMERICAN HIGHER EDUCATION}

The dilemma that has faced American higher education's relationship with the Black populace can only be understood by surveying the history of that relationship.

This relationship began with that era in United States history known as the slave era and reflects the impact of slavery on the consciousness of American society. It is in this era that the base of the problem of disproportionate illiteracy among the Black population

can be seen. This chapter examines the solutions attempted to overcome the condition of ignorance, a conditioned preferred by the slavemaster and the system that supported slavery.

This chapter will go on to show that the Reconstruction era (1865 - 1877) represented the highest point of egalitarianism and democracy reached in the United States of America. As will be shown, many of the colleges and universities that grant Bachelor and advanced degrees were formed around this time. However, the years preceding slavery lasted long enough to establish subordination of Blacks as a significant feature in the post-Reconstruction period of American mainstream culture. The Reconstruction era was very short lived.

The period that followed the Reconstruction era was characterized by a set of apartheid-like laws and practices, known as "Jim Crow," that disenfranchised a large proportion of ex-slaves. The attitudes of slavery were still strong and a derivative racism worked to block the mass education of Black youth. If the Black population were to be educated, racists and their representatives in government made sure that it was to be done on a level inferior to that of the White population through grossly unequal distribution of resources. 
From the end of the Reconstruction era, 1877, to the middle of the twentieth century, the battle for educational equity was waged in the courts. Education during that period was done primarily by Black "land grant" institutions surviving from the Reconstruction period. The case of the Brown v. Board of Education, 1954, signaled the end of a period ushered in by the case of Plessey v. Ferguson, 1896 (Pilgrim, 1985).

The 1950s and 1960s witnessed a national Civil Rights movement culminating in sweeping changes in American higher education, matched in intensity only by that of the Reconstruction era. As a result, for the first time in American history, more Blacks enrolled in Historically White Colleges and Universities (HWCUs) than Historical Black Colleges and Universities (HBCUs). However, as in the Reconstruction era, these successes were short lived and now appear to be reversing.

As this chapter will show, the history of Blacks in American higher education has been experienced as something of a "see-saw" experience, with most of the time being spent on the downswing. The current situation can only be seen accurately if the overall historical battle for educational equity is reviewed.

\section{Pre-Emancipation}

Questions about access and success for Blacks in higher learning, and more specifically, in Historically White Colleges and Universities (HWCUs), must take into account the environmental and subjective conditions for both the applicants to, and the administrators of, these institutions. Neglecting this assessment will prevent an accurate identification of the problems and deter recognition of required remedies.

Most important in this assessment of environmental and subjective conditions is the historical relationship between Blacks in the USA and American institutions of higher learning. Analysis of problems of attraction and access of Black students to HWCUs has 
often been divorced from lingering historically based attitudes established in American political culture during America's chattel slavery and post Reconstruction periods. The attitudes developed at this time have an analytically significant effect on HWCUs' ability to serve the Black portion of the American population. DuBois' (1970) statement is indicative of the Pre-Emancipation era:

It was soon after the [Civil] war that a white member of Johnson's restored Louisiana legislature passed one of the schools set up by the Freedmen's Bureau in New Orleans. The grounds were filled with children, He stopped and looked intently, and then asked, "Is this a school?" "Yes," was the reply. "What, for niggers?" "Evidently." He threw up his hands. "Well, well," he said, "I have seen many an absurdity in my lifetime, but this is the climax!" (p. 637)

The mass of ex-slaves were to have no education. The laws on this point were explicit and severe (DuBois, 1970). These attitudes have had a dulling effect on the sensibilities of America's institutional leadership reflected in the less than satisfactory response to the devastated lives of America's ex-slaves and their descendants. The following excerpt from an 1851 essay by a Georgia slavemaster on slave management and its relationship to the interest of southern agriculture is revealing of the rationalization and attitudes of the time:

It is not at all pertinent to the question that we should elaborate on the abstract institution of slavery. Suffice it to say that the institution as it exists with us is "a fixed fact", deriving its importance from necessity and humanity, and ordained by an All-wise Providence for wise and beneficent purposes, prominent amongst which is the improvement of the moral and social condition of the African race. In their treatment and management, then, it behooves us to regard them as persons and moral agents as well as property. Indeed, our duty in this regard on the one hand, and our interest on the other, are intimately connected. For in our proportion as the moral character of the slave is elevated, and imbued with correct opinions in reference to his moral obligation faithfully to discharge his duty as a servant, and to respect and venerate the authority of his owner, you make him a more faithful and obedient servant. How then can this desirable object be accomplished? Shall we educate him? Could this be done in safety, it would certainly be desirable that every slave should at least be taught to read. For if made conversant with the history of his race, and with the sacred precepts of Holy Writ, it would 
unquestionably have a tendency to reconcile him to his fate and to inspire him with gratitude to Providence for the delivery of his race from a state of barbarism to the society of Christian civilization and the lights and precepts of the Gospel. But the spirit of bigotry and fanaticism which are abroad in the country, seeking to disseminate a spirit of insubordination in the bosom of the slave, by the circulation of incendiary publications, inducing him to throw off the authority of those to whom his services are due, at once precludes the idea of such policy. (Bass, 1980, pp. 11-12)

During the more than three centuries of slavery on American soil, the education of Blacks was seen as a crime tantamount to treason. There were strict laws forbidding it in South Carolina, Mississippi, Virginia, Missouri, and other Southern and border states (Pilgrim, 1985). The enslaving society saw the education of the African slave as a precursor to a savage rebellion (DuBois, 1970; Pilgrim, 1985). The overlords of slavery believed that education had the potential to arm the slave with a double edged knowledge base. On the one hand the slave would know that the slavemaster was not omnipotent, omnificent or omnipresent, thus weakening the controlling instrument of fear used by the master. Secondly, the slaves would realize that the difference between the slavemaster and themselves was one of political and military might, not morality nor righteousness.

The self-assertion of an educated Black person in America, should a slavemaster encounter one, would cause immediate alarm at the possibility of widespread unruliness should this Black person become the social model for slaves. Even the president of the Union, Abraham Lincoln, shrank from the idea of free Blacks roaming America causing him to inquire into the feasibility of shipping them back to Africa or elsewhere after the Civil War (Bennett, 1966). The slavemasters, along with their influence in the Democratic Party and agricultural economic interests, did all that could be done to thwart the education of slaves.

The majority of slaves who learned to read and write did so in the great house, along with the children of the family. The Bible for many slaves was the Open Sesame to the mysterious letters of the alphabet and on many plantations the only 
book that slaves were allowed to own. The Sunday School at Lexington that Thomas J. (Stonewall) Jackson taught in 1845 included a few Negroes who had learned to read and write. Some years later, however, several white ladies of Falmouth were ordered to cease giving Negro children oral instruction in the religious classes that they conducted.

The most publicized school for Negro children during slavery was that established by Margaret Douglass, a white woman from South Carolina, who organized classes in Norfolk in 1853 for free Negro children. Arrested on the charge that slaves were among her pupils, Margaret Douglass denied her guilt. She was found guilty and sentenced to serve one month in the Norfolk City Jail. (Katz, 1969 , p. 265)

There were some Blacks who were educated before the Emancipation Proclamation and the 13th Amendment; however, most of them were freed former slaves not in bondage to any master. For their education they were mostly indebted to themselves or philanthropists of a religious bent. Occasionally a master would educate slaves to the point where they could read the Bible. However, this was commonly frowned upon and appeared not to be the rule. The custom accompanying slavery in the USA was that aside from technical information given on a need-to-know basis, slaves were not to be educated (Pilgrim, 1985). C. W. Birnie, a scholar of Blacks in South Carolina, enacted a law in 1740 which prohibited any person from "teaching or causing a slave to be taught, or from employing or using a slave as a scribe in any manner of writing" (Gordon, 1971, p. 83).

It must be remembered that the overwhelming majority of Blacks in the USA were slaves prior to 1865 (DuBois, 1970). Those slaves who did receive an education were the exception. Illiteracy of the Black population in 1863 was at $95 \%$, which meant that less than 150,000 of the four million slaves emancipated by the 13th Amendment could read and write (DuBois, 1970, p. 638).

Laws against Black education became strengthened and more strictly enforced after the 1831 insurrection of Nat Turner (Pilgrim, 1985). In 1862, a Lincoln-appointed Provisional Governor of North Carolina named Edward Stanley closed a school 
educating Blacks to placate the anger of local Whites. He stated that he was sent to restore the old order of things and that educating slaves to read and write was against the law (DuBois, 1970, p. 638). Educational progress for all Blacks, free and slave, of South Carolina "was seriously crippled after the Vessey insurrection in 1822. Laws were passed severely restricting the opportunities for Negroes to get education" (Gordon, 1971, p. 84).

Even Sunday Schools and Sabbath Schools were attacked:

For a brief period, slave owners, in an attempt to undermine secret schools, allowed blacks to attend Sabbath schools. Slaves were taught to read, memorize, and practice selected scriptures. Biblical scriptures became a means of social control. When slaves read, "Servants, be subjected to your masters with all fear not to the good and gentle, but also the harsh" (1 Peter, 2:18), they were confronted with a moral dilemma, emancipation in this world or glorification in the hereafter. White supremists, frightened by several uprisings led by black religious figures, resolved the slaves' dilemma by closing and outlawing the Sabbath schools. (Pilgrim, 1985, p. 7)

Noted scholar Carter G. Woodson (1968) wrote that in the year 1830, a riot known as the "Snow Riot" took place in Washington, D.C. in which Blacks were attacked because of an allegation that a Black restaurant owner made insulting statements about the wives of some White mechanics. According to Woodson, this was just a ruse to "get rid of the progressive Negroes of the District of Columbia" (p. 134). One of the results of this riot was the closing of Sabbath schools to the district's Black population.

According to Pilgrim (1985), the burning of the few Black schools that did exist in the North was not uncommon in that time. Teachers were harassed and, along with their students, lived in constant fear of being whipped, jailed, or sold into slavery (Pilgrim).

Until slavery ended, Blacks who did receive higher education either received it in Europe or were sponsored by the American Colonization Society. If the latter organization sponsored the education, the student could study at one of the select 
Historically White Colleges and Universities (HWCUs), but was then bound to migrate to Liberia (Pilgrim, 1985).

It must be noted here that American colleges and universities in the USA were not only off limits to those of African birth or descent but were also restricted for the poor of European descent as well. In fact, public education, which was the only type that poor Whites could have access to, did not exist until America's "Reconstruction" period (Du Bois, 1970). Institutions of higher education divided the White population along class lines; in terms of the Black population, institutions of higher education followed caste lines.

Apologists for the slave system, using a racist ideology as their frame of reference, claimed that Black persons were unable to learn (DuBois, 1970). Given this reactionary attitudinal context, it is no wonder that the first organized educational institutions of Blacks in the USA were established by Blacks not under the direct yoke of slavery. The first "independent" Black elementary school dates back to 1798 (Conciatore, 1989, p. 12).

For children of African descent, unlike those of European ancestry, acquisition of wealth and property provided no passport into the noble institutions of higher learning. Racist attitudes and ideology originally designed to perpetuate slavery would, as time went on, obstruct economic alliances. Reconstruction-period state government sponsored education policies, provided for the first time, were short lived as a result.

\section{Reconstruction Era Through Brown v. Board of Education (1865 - 1954)}

In the year 1860, only 28 Blacks had graduated from colleges in the USA (Pilgrim, 1985, p. 8). Education in the slavebased U.S. economy and society traditionally excluded Blacks (Flemming, Gill, \& Swinton, 1978). It was not until the official ending of slavery 
with the 13th Amendment and the subsequent defeat of the agricultural slave system elites of the South that we begin to see the establishment of colleges designed to educate Blacks in the USA. This occurred during the short period known as Reconstruction, 1865 -- 1877.

On the heels of the Civil War there appeared to be another America on the horizon. For the first time in America, colleges were formed to serve the Black population. Notable among those first colleges was Howard University, established in 1867 and named after its founder, General O.O. Howard, then head of the Freedmen's Bureau (Pilgrim, 1985, p. 9).

However, things were generally not good for Blacks in America in terms of education. While change for the better had been experienced as a result of the reforms enacted during the Reconstruction period, the Plessy v. Ferguson case, 1896, case signalled the return to the social relations of the Pre-emancipation era. In Plessy $v$. Ferguson, the Supreme Court wrote into American law the doctrine of racial classification and separation. State laws requiring "separate but equal" accommodations for Blacks, the Supreme Court said, were a "reasonable use of state police power" (Bennett, 1966, p. 232). Thomas F. Gossett, in an article titled, "Racism At The Turn Of The Century" (1972), states:

Only a year after the Plessy v. Ferguson decision of 1896 we find James K. Vardaman in a campaign against Negro education in Mississippi. The state, he complained, was spending half a million dollars a year to prepare the Negro for "the higher duties of citizenship." Everybody knew that the Negro would not be allowed to be a citizen. His vote would either be "cast aside or Sambo will vote as directed by the white folks." Money spent on education of the Negro was a "positive unkindness to him." It rendered him "unfit for the work which the white man has prescribed, and which he will be forced to perform." Vardaman objected just as much to money sent by other northern philanthropists for private Negro colleges in the South. "What the North is sending the South is not money but dynamite," he exclaimed. "This education is ruining ur Negroes. They're demanding equality." When he became Governor in 1900, he drastically reduced the amount of state 
money spent for Negro schools. The only kind of education he thought suitable for the Negroes was vocational education and not much of that. The state colleges for Negroes in Mississippi were closed. (pp. 109 - 110)

Aware of an ever-present racism, Blacks evolved their own response to their needs for higher education. The Black community had a perception of education as a key to liberation, development, empowerment, and improvement. That perspective was an important link in the community's strategy for breaking up the vicious cycle of poor housing, poor health, unemployment and underemployment. It was the impetus that caused the Black population to form their own institutions of higher learning. Using the resources available and soliciting support from all friendly philanthropic sources, Blacks set out to educate their own. Fisk University opened in January of 1866; Morehouse College and Howard University were opened during 1867 . For more than eighty years, Black run colleges were the primary source of Black college graduates. Even today, most prominent names in the Black community trace their academic experience to these institutions. Jesse Jackson is a case in point.

The practices and ideology of racism in the USA persisted. According to Pilgrim, between 1930 and 1939 there were no less than 119 lynchings of Blacks (cited in Guzman, 1969, p. 58).

Even in the relative "liberal" climate of northern universities, only a handful of black employees escaped the crippling effects of racial discrimination. In 1936, a considerable number of black Ph.D.'s were available for employment, but fully 80 percent of them taught in three black institutions: Atlanta, Fisk, and Howard. The other 20 percent were employed at less prestigious black colleges. Between 1937 1947, 279 blacks received doctorates from American universities; however, in 1940 no blacks held tenured positions in any historically white American university. ... . Indeed, white administrators and faculty were major obstacles to black employment in white universities. (p. 36)

Prior to the 1960 s, it was common practice to prohibit Blacks from attending the HWCUs. In the southern states, as late as $1952,100 \%$ of the Black college students attended 
HBCUs (Nettles, 1988a, p. 35). As a matter of fact, only the HBCUs had large minority populations prior to the 1960s (Ferris, 1979).

\section{Civil Rights Era}

A small number of Blacks began to attend HWCUs in the late 1950s. Students became confounded and enraged at the falsehood of the, separate-but-equal doctrine pushed by Jim Crow administrations. Sparked by massive campaigns of Blacks from various sectors of the community, Black students continued the school desegregation movement, with the goal of putting an end to racial segregation in the schools.

With the education obtained came the desire to share in the resources and opportunities of the USA as provided by the United States constitution. Those desired resources included access to the better endowed HWCUs. Educated to the provisions of the constitution of the USA for all of its citizens, Blacks began to test the sincerity of the document's noble ideals which, however, did not include education for all. Demands for an equitable share of the educational opportunities resulted in the Brown v. The Board of Education, 1954, case. Willie (1987) stated the following:

In "Brown", the Supreme Court exposed the basic inequality of dual educational systems, thus setting in motion a chain of events that challenged long-standing precepts and propelled an often reluctant nation into the midst of dramatic changes. (p. 38)

Black college students were change agents for educational access. Black college students, in the 1950s, played a significant role in the Civil Rights Movement. Most of these students were educated in the HBCUs. They were responsible for initiating the well known "sit-ins" and "pickets" that sought rights beyond mere educational access at Hampton, Norfolk, Newport News, Portsmouth and Suffolk, Virginia; in Tallahassee and 
Deland, Florida; and in Nashville, Tennessee (Orum, 1972, pp. 2-9). Orum stated the following:

Indeed, on all fronts the response of people to the student-inspired protests was overwhelming. Many white clergymen, politicians and labor representatives offered their support and urged the students to persevere with the demonstrations. Some went so far as to endorse the moral validity of the student protests.... The student demonstrations also had the effect of arousing the civil rights groups.... More than twenty states and almost 100 cities, most of which were in the South, had witnessed sit-ins, picketing or boycotts on the part of students and their sympathizers. According to the Southern Regional Council, at least 70,000 blacks and whites actively engaged in demonstrations and rallies. And more than 3,500 people, for the most part black students, had been arrested. (p. 5)

Demands for civil and human rights threw the USA into a violent social upheaval. The Brown v. the Board of Education, judicial findings, 1954, represented a legislative victory leading toward access to the HWCUs. Abdul-Khabir (1986) suggested that the "urban rebellions" and spontaneous outbreak of violence may have had as much or more of an impact than the sit-ins, marches and pickets. He further asserted that the HWCUs actively recruited those youth who would potentially lead these actions in an effort to head them off.

The gap between legislation and execution consisted of inadequate philosophical models, understanding, conviction and commitment.

\section{Blacks Attendance At HWCUs Increased As HBCUs Remained Steady}

Though the federal data is fraught with errors (Howard, 1976), some basic conclusions can be drawn about the increase of access for Blacks in Higher Education during the period following the initiating of Title IV programs provided for in the Civil Rights Act of 1964 (Howard, 1976). Blacks made significant gains in Higher Education in the 1960s and held steady in the early 1970s (Howard). For the first time in the history 
of the USA, more Blacks attended HWCUs than HBCUs (Bolden, 1986; Ferris, 1979; Howard, 1976; Nettles, 1988; Stikes, 1984; Wiley, 1990). In fact the majority of Black students enrolled in an institution of higher learning attended HWCUs (Bolden, 1986; Howard, 1976; Nettles, 1988; Stikes, 1984). However, HBCUs were still responsible for a disproportionately high amount of the Black Bachelor degrees awarded (Howard). Much of the success can be attributed to actions taken on the federal, state and local levels (Howard).

Another key in this success was the establishment and expansion of "special admissions" programs affiliated with Educational Opportunity Programs (Ferris, 1979). While it should be noted that the G.I. Bill was a precursor of this kind of effort, this new group of students represented a culturally diverse population shift for most HWCUs (Ferris). There was resistance on the part of a number of states, notably but not exclusively in the South (Brown, 1988; Pilgrim, 1985); but federal pressure in the form of monetary support held sway. Thus, the resources provided by federal financial aid programs proved to be a significant factor of success (Carter, 1989). The proportion of Black students participating in grant programs such as the BEOG and SEOG (later called the Pell Grant) and low or no interest loans such as the National Direct Student Loan (NDSL) was greater than the proportion of Black students enrolled in college (Howard, 1976, p. 6).

Until 1975, improved enrollment access looked promising but the pendulum of federal support was in the process of swinging in another direction. The GrammRudman-Hollings Bill and other government policies directly decreased federal support (Carter, 1989; Wiley, 1990b). This change of position would lay bare the resistance of those state and local policy makers who seldom felt the responsibility of this committed direction was theirs to bear (Pilgrim, 1985). The result was a reversal of support reminiscent of the reversals marking the end of the Reconstruction Era, a century earlier, 
in which the federal government left the plight of Blacks in the hands of local authorities.

By 1975 the enrollment success began to roll backwards (Howard, 1976, p. 20).

\section{Decreases in Support Systems for Black Students}

Studies have shown that enrollment rates are positively associated with money spent on student aid (Carter, 1989). Federal assistance for financial aid and academic support programs were key to the nationwide increase of Black enrollment in higher education from 1966 through 1976 (Sudarkasa, 1988; Carter, 1989). While a College Board study showed that a record 20.5 billion dollars was spent in 1986-87 on financial aid, when adjusted for inflation, this figure actually represented a $6.1 \%$ decrease from the 1980-81 period (Carter, p. 96). A summation of the 1985 American Council on

Education's report by Carter states that:

1. The value of grant aid plummeted from 40.4 percent to 25.7 percent of total student expenses. Pell Grant funds awarded to students attending independent institutions fell 34.5 percent in constant dollars.

2. Reliance on loans increased from 12 percent to almost 20 percent of total student expenses over four years.

3. Students and their parents are paying an increasing share of the costs of attending independent institutions, up from 53 percent in $1979-80$ to 65.5 percent in 1983-84.

4. Institutional aid, awarded to three out of every five federal aid recipients, has more than doubled to almost $\$ 2$ billion annually in the two years between 198182 and 1983-84. (pp. 96 - 97)

Though our focus is the HWCUs, the impact of decreased financial aid monies was especially disastrous for the HBCUs in that over $80 \%$ of their student bodies had received some form of financial aid (Carter, 1989, p. 89). Financial support for institutions of higher learning has consistently decreased while tuition and fees have increased (Ferris, 1979). 
In 1981, passage of the "Reagan Era" Omnibus Budget Reconciliation Act put limits on the Pell Grant which previously had mandated that the government appropriate whatever funds necessary to serve all eligible students (Carter, 1989). Thus, only the lowest income students were still eligible for a full Pell Grant. Over a 15 year period, from 1970-71 to $1985-86$, student dependence on loans had jumped from $\$ 1.5$ billion to over $\$ 10$ billion. These loans were increasingly the more expensive Guaranteed Student Loans. Education was becoming increasingly a debt challenge (Carter, 1989; Devarics, 1990).

Another obstacle for students using financial aid was the daunting bureaucracydriven paperwork with which recipients had to deal. David Evans, staff director of the Senate education subcommittee, headed by Senator Claiborne Pell (after whom Pell Grant was named), stated, "Every year [Senator Pell] gets a copy of the Pell Grant application. Every year it comes back with the same comment: 'I can't figure it out'" (Devarics, 1990, p.12).

However, the critical nature of the financial aid factor for Black students becomes more apparent when one considers that in 1981, nearly half of Black college-bound seniors came from families with incomes under $\$ 12,000$, as compared to about one tenth of White students (Carter, 1989). In 1987, 30\% of Black families in the USA received an income less than $\$ 10,000$ as compared to $25.7 \%$ in 1970 ; for White families this figure was $9.3 \%$ and $9.6 \%$, respectively (Swinton, 1989, pp. 13-21). In 1970, the Median Family Income for Black families was $\$ 18,378$ and by 1987 it had fallen by $\$ 280$ to $\$ 18,098$ while the White Median Family Income rose by $\$ 2,314$ from $\$ 29,960$ to $\$ 32,274$ over the same time period (Swinton, pp. 13-21). These statistics from the U.S. Department of Commerce, Bureau of the Census, show a growing downward trend for Black families in the USA. These facts become exacerbated when one is reminded that 
the average Black family is larger than the average White family and more often headed by one adult (Swinton, p. 12).

The deteriorating economic conditions of the Black community worked against the academic progress of its students. A number of recent tests have shown that Scholastic Aptitude Test scores directly corresponded to the family income level of the test taker. Those who achieved higher scores came from higher income brackets while the lowest scores came from those in the poverty category.

Predictive factors such as race, type of high school attended, and racial composition of high school attended were associated with time periods for graduation from HWCUs (Brown, 1988). Thus, Black students end up paying more for an education at HWCUs than white students though they are the least able to pay.

When federal assistance decreased as of 1976, the HWCUs had the choice of supplanting this assistance with their own funds or risk declining percentages of low and mid-income Black high school graduates enrolling at their campuses (Ferris, 1979).

This decrease in federal assistance in the face of an increased demand for financial aid causes one to doubt the commitment of the majority society and its representative educational institutions, as HWCUs are seen to be in the Black community. During the late 1960 s and early 1970 s, most financial aid went to low-income Whites and Blacks. Sudarkasa (1988) observed that:

As.the numbers of other minorities in higher education increased, and as middle class whites demanded financial aid assistance, there was a commensurate need for additional financial aid dollars. The response to this increased demand was to cut the financial aid pie into thinner and thinner slices. (p. 11)

In summary, one must take into account the ideological and attitudinal precedents formed in the USA during the period of chattel slavery in order to understand the failure of the country to provide higher education for its Black population. The temporary gains made by Blacks came as a result of organized agitation by Blacks and support by the 
federal government. However, neither component could sustain those gains over time. Blacks did not have sufficient resourses to sustain the large and compelling coalitions to continue the agitation needed. The federal government lacked both the will and consistency to continue the support without this organized pressure.

In fact, the general culture of the HWCUs continues to reflect the legacy of the historically contradictory relationship between the slaving society and the slaves and the descendents of the slaves. As will be seen in the next section, when federal authority is absent this obstacle appears to outweigh all others. 


\section{A DISCUSSION OF THE CULTURAL FACTOR}

This chapter examines the cultural factors that led to the decreased educational access for Blacks to American higher education. The University of California is used as a case in point for this chapter because it is a public university system in one of the most ethnically diverse states in the country. Included is an assessment of the impact of decreasing federal support, rising racial intolerance and curricular insensitivity. The roie of cultural awareness among and throughout the American academy is asserted as a critical requirement to reverse the current failures of the country's educational system.

Cultural values of the Black community were juxtaposed with the cultural values within Historically White Colleges and Universities (HWCUs). The cultural values of the latter mirror the general cultural values of the dominant society in relation to the Black community. Obstacles that arose from these differences are discussed. From this analysis, the chapter expounds on the HWCUs' image in the Black community.

Institutional unawareness and insensitivity and pejorative attitudes toward those of African descent are significant factors in the deteriorating situation of Black access and success in HWCUs. Lofty declarations of commitment to diversity by these campuses do not obscure the increasing levels of acts of overt campus racism and federal abandonment of support for financial aid. Finally, the eligibility formulas used by many HWCUs, in light of admitted deficiencies of the K-12 public education system, express an ubiquitous pattern of victim blaming.

This chapter raises questions as to whether the HWCUs, especially the University of California system, which has a mandate to serve the ethnically diverse public of California, are prepared to serve the diverse segments of society. A case is made here that studies done thus far have asked the wrong questions. These studies are marked by preoccupations with the preparation level of the Black students, but have not asked the 
question of the preparation level of the institutions that are to provide the services. This issue becomes important in light of the fact that prior to the $1960 \mathrm{~s}$, the largest influx of non-traditional students came with the advent of the G.I. Bill. The group that entered the HWCUs at that time was predominantly veteran, older than traditional students, and more diverse in terms of class background but not very different in terms of cultural. The group that came in during the Civil Rights era was a more heterogeneous group than those that gained access through the G.I. Bill and therefore had a different set of needs. Until the HWCUs address the needs of this new population, their proclamations about commitment to diversity will be seen as a contradiction at best and an insult at worse.

\section{Cultural Conflict Retards Black Student Success Potential at}

\section{Historically White Colleges and Universities (HWCUs)}

College completion rates are rapidly becoming a general problem of colleges throughout the country. The completion rate of Black students at historically White colleges and universities (HWCUs) has been lower than that for the mainstream population. Reasons for this problem are: a) decreasing financial aid and ethnic programming support as a result of decreasing federal support and pressure; b) rising overt and covert racial intolerance; and c) curricular ethnocentricity and insensitivity in curricular planning. The HWCUs, in general, and the University of California system, as a case in point, are not immune to any of these problems. In fact, these problems are crucial obstacles blocking the success of Black students at these institutions.

Educational institutions do not change as easily as the demands made upon them (Ferris, 1979). The arrival of Black students at the HWCUs engendered its own set of sociological and cultural problems. The culture of the Black community has been pejoratively viewed in much of the sociological literature of authors such as Moynihan 
and Glazer. This literature presents culturally-based adaptive responses to systemic exclusion as "deviant" by those who regard Black cultural traits as a result of slavery and poverty. The real affliction of poverty in this case may be the misperceptions of those who do not recognize the holistic impact of culture. The culture of Black people predates their arrival as slaves into the Americas. In fact, Black culture in the USA is a reflection of surviving Africanisms (Stikes, 1984).

The outlook of the HWCU toward the Black student and community reflects the contradiction between Western, or European culture, and African cultures. The Western, or European, worldview relates to the African worldview in an often contrasting manner. In the education field, this contrasting relationship becomes intense and achieving a meaningful interaction requires knowledge, will and commitment for all involved. The first requirement is an understanding of cultural nuances.

A people's culture is a total way of life (Stikes, 1984; Toure, 1976; Cabral, 1973). It reflects the material elements, such as artifacts and tools, as well as the nonmaterial elements, such as beliefs, values, attitudes, expectations and behaviors (Stikes, 1984). These things are used and displayed by individuals in a social group as well as between various social groups. Human culture has both universal aspects and particular manifestations among various peoples (Toure, 1976). It is these particular variations that cause different peoples to respond in different ways to similar stimuli (Brown, 1988).

Colleges and universities are cultural institutions that have philosophies and ideologies that are reflected in the framework of their functions. The philosophy and ideology that underlies HWCUs is basically the same one that underlies the Western, or European, society. Individualism, elitism, and sectarianism permeate this worldview and have disastrous effects when applied to the African world experience. The African worldview, a product, condition and mediating factor in the African world experience, downgrades individualism to ensure community complementarity and intricate mutual 
support systems; discards elitism to safeguard community harmony; and abhors sectarianism to protect collective unity (Anderson, 1989). The Western world view of the HWCUs and the more African oriented world view of the Black community are often incongruent and this is reflected in the disfunctionality seen in the recruitment and retention practices of the HWCUs.

Historically, access to the HWCUs was the prerogative of a small fraction of men and women drawn from the upper income mercantile, industrial, and professional classes (Ferris, 1979). This affected the curricular content, problem solving strategies and norms of academic success of these institutions. In terms of a general cultural approach, many of the HWCUs discussed in this paper should be classified as "monoversities" as opposed to universities for they have lacked universal dimension and representation. HWCUs' faculties have been overwhelmingly comprised of middle to upper-middle income class White males (See Table 1).

These faculties are microcosms of the ruling/management stratum in America. HWCUs' core requirements and the central theme of their content have been oriented toward the historical values, customs and manners of the European experience as influenced by their elite aristocracies. For example, there are thousands of languages in the world, yet HWCUs have treated non-European languages as exotic subjects while they have treated the limited variations of European languages as the norm. History, philosophy and ethics have been taught as if those subjects originated and were perfected in Europe or in some part of the world that Europe "discovered." This inaccurate and prejudicial perspective has been further projected onto the fields of science and math. African, Arabic and Native American contributions to science and math have been seldom, if ever, mentioned. The total packaged curriculum has been cloaked in the mantle of objectivity in a highly subjective process by the faculty that constructed it. 
Table 1

University of California Personnel ${ }^{a}$ Comparison By Ethnicity

\begin{tabular}{lcccccc}
\hline Type & Total & Percent & White & Percent & Black & Percent \\
\hline $\begin{array}{l}\text { Executive } \\
\text { Program }\end{array}$ & 281 & 100 & 256 & 91 & 10 & 4 \\
$\begin{array}{l}\text { MAP } \\
\text { Programb }\end{array}$ & 1,386 & 100 & 1,195 & 86 & 62 & 4 \\
$\begin{array}{l}\text { Academic } \\
\text { Staff }\end{array}$ & 33,774 & 100 & 26,336 & 78 & 645 & 2 \\
\hline
\end{tabular}

Note. Data from University of California Admissions and Outreach Services Information Digest, September 1987, pp. 40 - 42. a Contract workers were not included. b MAP is a middle management classification.

Following the concept that what is good for General Motors (i.e., big business) is good for America, the HWCUs faculty seldom hid their direct allegiance to big businesses or government agencies (Smith, 1974). Some educators have seen it as their mission to prepare the youth to serve these very interests. When this is the case, their integrity as objective scholars is compromised. In the University of California, a contract with a major business or government agency heaps enormous accolades upon the faculty member who is instrumental in securing it. In a nutshell, this person has brought money to the campus. Often this desire for an increased resource base will cause the institution 
in question or ignore the fact that the granter of the contract may be involved in activities that are known to be unpopular.

Many articles have chronicled the battles that had to go on before the various campuses in the University of California system reluctantly divested from companies with known ties to the apartheid system in South Africa. Mock shanty towns were built on UC Davis' campus and a protest rally was held at UC Santa Cruz in which a large portion of the student body participated. These students were dumbfounded by the rhetoric proclaiming disgust with Apartheid expounded by the educators and administrators while the UC system, as a business, maintained profitable connections with the "Nazi-like" regime.

Probably the most dubious relationships that the University of California system has had, have been with the Military Industrial Complex, Nuclear Regulatory Commission and the Industrial Police Intelligence Complex. Its relationship with the Military goes back to the second World War in which the University of California was instrumental in the research and development of numerous weapons systems. Most notorious among these was the Atomic Bomb. This path began to threaten the integrity of the University. In an article titled, "U.S. Military And Higher Education" by Richard Abrams (1989), Abrams wrote:

Amid the unending tensions of the post-war era, Americans' call for their universities to service national policy priorities -- especially some that required or made use of some secrecy and deception -- would put at risk higher education's own priorities for promoting honest and independent scholarship and teaching. (p. 16)

However, faculty tenure and promotion depended on knowing what side the bread was buttered and most responded appropriately. In his revealing article, "Consequential Controversies," David A. Wilson (1989) stated that:

Clark Kerr, then president of the University of California, published his 1963 Godkin lectures, The Uses of the University (Cambridge, MA: Harvard University 
Press, 1963), in which he discussed in one lecture "the realities of the federal grant university." In it he pointed out that 75 percent of all [federally funded] university expenditure on research [included] 32 percent from the DoD [Department of Defense]. He made a number of observations about the consequences for internal cohesion and control of this situation. (p. 47)

Mr. Wilson went on to state that, "because of the imperatives and dominance of military funding, disciplines are skewed in significant ways" (Wilson, 1989, p. 53). Another example follows below.

In its February, 1988 issue, The Progressive carried an article that exposed the employment of a Central Intelligence Agency (CIA) senior member as an appointed faculty member. Harper's Magazine, March 1988, reprinted the letter from Stanley Moskowitz, chairman of the CIA Training Selection Board, to Professor Dean Mann, then chairman of the political science department at the University of California at Santa Barbara. The letter ran as follows:

Dear Professor Mann:

The Central Intelligence Agency is pleased to learn that the University of California at Santa Barbara is interested in accepting an Officer-in-Residence as part of its faculty. Our nominee to your school is Mr. George A. Chritton Jr. We would appreciate your considering him for a position in the College of Letters and Science in the political science department. A curriculum vitae on $\mathrm{Mr}$. Chritton is enclosed.

The Central Intelligence Agency's Officer-in-Residence Program provides an opportunity for senior-level officers to disengage from their normal duties by fully participating in the academic life, including research and teaching. The Officer-inResidence, who is identified as a CIA officer, by his presence will demonstrate the quality of CIA people and our commitment to providing U.S. leaders with the very best intelligence we can. The program also serves to strengthen our professional ties to a fertile and indispensable source of ideas and technical expertise and to enhance the CIA's recruiting efforts by providing an opportunity for experienced officers to serve as role models, to counsel interested students on career opportunities with the CIA, and to respond to concerns students may have about the agency and the intelligence profession.

The university will gain an officer who can effectively provide practical knowledge and experience to the institution and students. The officer is assigned without cost to your institution. All funds are provided by the Central Intelligence Agency. (p. 26) 
Condemnation of these agencies' practices is seldom found in University of California sponsored journals. However, while trying not to offend the sponsors of some of these programs, the University of California system should be aware of the unfavorable image these agencies have in the Black community. Institutions cannot "run with the hare and hunt with the hound!"

Like class, the importance of culture has too often been played down and relegated to a peripheral position at HWCUs. At the same time, these campuses are oftentimes quoted as expressing an intense rhetorical desire for the establishment of a multicultural campus. Yet, the commitment of resources and the readiness to relinquish the deeply imbedded cultural assumption of European superiority remain absent. A widely visible traditional arrogance has been supported by a form of cultural superiority which has postulated that other peoples must imitate Western culture in order to be validated. As a result, the culture of an Africentric or Indiocentric people, for example, is not given its due acknowledgment; it is in fact, unrecognizable in the monocultural context of Eurocentric mainstream American social discourse.

History provides lessons about the importance of culture to the Black community. Black students demanded, sometimes violently, that their culture be recognized on HWCUs during the 1960s and early 1970s (Abdul-Khabir, 1986). The arrival of Black students at the HWCUs was an event for which campuses were obviously underprepared. Neither the cultural content nor context at HWCUs reflected the world that most Black students had known. This did not mean that they were unfamiliar with the mainstream cultural values that they encountered, for Western culture permeated their society. The challenge required to obtain a degree in higher education was accepted by this group as it was by the dominant society. Indeed, the presence of Black students on mainstream college campuses demonstrated some acculturation to the mainstream . However, studies 
confirm, Black students of that era expected more from a university setting in terms of cultural support. These students did not demand that Western culture not be present, only that their culture also be included in formal and informal ways. Brown (1988) stated:

The exclusion of Black students from campus social networks, in conjunction with unsatisfactory interpersonal relationships, causes Black students to experience many psychosocial difficulties and feelings of alienation; consequently withdrawal behavior is frequent. ... In many instances, psychosocial, rather than academic problems provide the most powerful explanation of low performance and high attrition among Black students on white campuses. (p. 59)

Social relationships are an important part of the college experience and should serve to enhance and reinforce values and behaviors learned in the classroom (Brown, 1988). Brown went on to say:

For many Black students attending white universities, however, campus social relationships are anything but positive. These students feel the heavy burden of racial discrimination (sometimes subtle, but frequently not) and face daily attempts to denigrate their personalities and culture. ... Since they are often not privy to -or are alienated from -- established . Jcial networks on their campus, these students find it necessary to spend valuable ime in the construction of Black social support systems. In many instances, universities are either ignorant of and/or unresponsive to the special needs of Black students, further complicating their adjustment to college. (p. 59)

Black students seldom have the luxury of being passive in the face of uncomfortable environments for these environments are becoming more and more hostile. Racial incidents have increased steadily in recent years (Associated Press, 1989a; Associated Press, 1989b). This increase has come while the Office of Civil Rights (OCR), since 1986, has had its resources cut due to federal abandonment (Devarics, 1989). Most of the complaints coming to the OCR come from the Education Department's Region IV -- the southem states (Devarics). These states are not the exception but had a large number of cases due to the concentration of Black students in this area. In the past decade, racial incicents have been reported at colleges across the 
country. Though no one keeps statistics on such incidents, officials at the colleges and experts in race relations say they seem part of a growing pattern of bigotry and animosity toward non-White students on campus (New York Times, March 9, 1987).

The following is an article written by a Black undergraduate student while enrolled at the University of California at Santa Cruz (UCSC). In it some specific national examples with a focused eye on California are displayed:

-At Columbia University, 30 white students chased and beat six African students. -At the University of Michigan at Ann Arbor, an anonymous flier declaring "open hunting season" on African people was found in a dormitory housing [of] some African women students.

-A mob of hundreds of white students at the University of Massachusetts at Amherst chased and beat four African students with fists and baseball bats after the Boston Red Sox lost to the New York Mets in the World Series.

-At the Citadel Military Academy in South Carolina last October [1986], five white cadets dressed in KKK outfits burst into the room of an African cadet and burned a paper cross in front of him.

-At the University of Alabama in Tuscaloosa, a cross was burned in front of a new African sorority house.

On this campus, we continue to see displays of overt racism. The following is in not an absolute list:

-Several white male students spit on two African women students at Merrill College.

-In the Porter College newsletter, Heap of Hoot, there were references made toward the African students of Oakes College as being monkeys (the piece was defended by the publishers as satirical).

-Five white male students pulled a gun and assaulted one African male student with a crowbar and viciously kicked a Chicano student in the head, at Merrill College. -As part of a cultural awareness event, Stevenson College invited a group of local breakdancers to perform who were later referred to as "strapping young bucks, who could contort their bodies ..." in the Stevenson newsletter.

-Most recently, on the night shuttle a group of white students made derogatory racial references [directed toward] the presence of a group of Asian students. In regard to several overtly racist incidents in UCSC's history, the institution has done little more than slap the offenders on the hand. This indicates that such behavior isn't really acceptable, but not [a serious enough trangression to merit more serious consequenses]. (Williams, 1987, Spring, p. 7) 
The reader should be aware that UC Santa Cruz was not the only campus in California to experience this type of event. It is unlikely that there is a HWCU in California or anywhere else in the nation that can make the claim of not having had this problem to one degree or another. The problem had become so enormous in California that State Senator Art Torres organized a Senate Special Committee on University of California Admissions which had the charge of investigating the racial/ethnic tensions which "have erupted on our nine University of California campuses over the past few years" (Letter to Terrence Charles from the Senate Special Committee on University of California Admissions, 9/12/88). In Senator Torres' letter, which invited students to attend an October 4, 1988 meeting at UCLA, he said,

I believe the racial tensions which have plagued the University are no longer simply individual campus issues, but rather problems which warrant immediate statewide attention.

There has been an enormous rise of racial incidents occurring on campuses nationwide, for example, instances of intergroup conflicts were reported on approximately 70 college campuses during the academic year 1986-87. The University of California has recently itself experienced a number of highly publicized racial/ethnic incidents which contributed to a trend of racial unrest and ethnic discrimination occurring throughout the nation.

The discord on our University of California campuses is not only detrimental to our undergraduate and graduate student retention rates, but may also have the unintentional effect of hindering a large number of applications to the University for fear of racial confrontation and alienation. (A. Torres, personal communication, October 4, 1988)

Overt, student to student, racism is the most publicized yet not the most deadly or pervasive form of racism at HWCUs. The covert racism imbedded deep in the functioning of the institution deserves attention. Williams (1987, Spring) said it this way:

Covert racism is very much an integral part of institutional racism. It's this insidious "I can't put my finger on it" type of racism which is at the core of the academic experience. James Jones, a social psychologist, offers a definition for institutional racism: "Those established laws, customs, or practices which 
systematically reflect and produce racial inequalities [that] are in American society." If racist consequences occur from institutional laws, customs or practices, the institution is racist whether or not the individuals maintaining those practices have racist intentions. (p. 7)

The root of this covert dimension can be found in the academic elitism and institutional racism that exists at the HWCUs (Ferris, 1979). Ferris said this is displayed by the belief in or application of the following myths:

(a) that the three separate [dimensions] of

1. admissions criteria

2. human intellect

3. academic standards

are one and the same entity and, therefore, the admission to college of students with disadvantaged educational backgrounds (i.e., specially-admitted students) is lowering colleges "standards."...

(b) that most of the academically superior cultural ethnic minority students go to Harvard, [UC] Berkeley, Yale, etc., and therefore, the rest of the colleges are left with ethnic minority students who are specially-admitted and are intellectually inferior to regularly-admitted, "traditional" students. ...

(c) that the ethnic minority students in college are getting a "free ride" while, bright, ethnic majority students ... are being kept out of college altogether....

(d) that all or most of the ethnic minority students in college are from economically and educationally deficient backgrounds. Hence, if one has a black or Spanish-surnamed student in class, for example, one may safely assume he/she will have academic difficulties. (pp. 91 - 92)

Images often lead to policies. This is especially true for an institution that prides itself in demonstrating excellence. Accordingly, if potential students are lacking in what it takes to achieve this excellence they should be kept out. The discussion around Black students' potential has been often focused on what they lack. The image of, thus expectation of, deficiency leads ultimately to the policy of exclusion. So while the HWCUs made statements about desiring a more ethnically diverse campus community they designed policies that worked against those goals.

Proof of the gulf that exists between statements and implementation was illustrated by the state of California's "Master Plan." According to this plan for education, the top 
$12.5 \%$ of California's graduating high school class was to be provided space on the 9 campuses of the University of California. The term, "top" is defined by a student's grade point average (GPA) in certain "college preparatory courses" (1 year of U.S. History -- or -- 1/2 year of U.S. History and 1/2 year of U.S. Government or Civics; 4 years of "college preparatory" English; 3 years of "college preparatory" Math; 1 year of Laboratory Science; 2 years of Foreign Language; and 4 years of College Preparatory Electives), referred to as "a-f" subjects, along with their Scholastic Achievement Test (SAT) or Academic Collegiate Test (ACT) scores. The GPA and test scores are used as indicators of preparedness and therefore eligibility for the University of California (UC). In 1983, if a student had a 3.4 GPA in college preparatory courses and had taken either the SAT or the ACT that student was eligible for admission into the UC system.

In setting criteria to establish this top $12.5 \%$ eligibility pool, there was no consideration of the documented reality factors influencing grade and test score outcomes for low income and historically excluded ethnic minority populations. Black students were a relatively lower income group when compared to the total population. As a result of this sociological problem, while 13.2\% of California's public high school 1983 graduates were eligible for admissions to the University of California, only $3.6 \%$ of Black 1983 graduates were eligible for admissions (California Postsecondary Education Commission [CPEC], 1985, December, p. 5). This meant that out of 23,288 Black graduating high school seniors in California only 838 were eligible for admission (CPEC, 1985, December, p. 5). The disparity becomes compounded when one considers the fact that Black public high school graduates in California were $9.1 \%$ of the total graduating class but were least likely to be admitted, according to the University of California's eligibility criteria (CPEC, 1985, December, p. 5). A young Black male has a better chance of being murdered than being eligible to attend the University of California 
(Haycock \& Navarro, 1988). It would seem that Blacks were being prepared for a role different from that of a university educated population, intentionally or not.

The status of Black student eligibility causes one to question the degree of commitment of the UC system in regards to its stated objective to increase the number of Black students enrolled in and graduating from the UC system to a point of parity. The position of economic and political underdog held by the Black community is no secret to the University of California as is displayed in publications produced by the Task Force On Black Student Eligibility.

The impact of this underdog position on the formal educational experience has been well documented (Sudarkasa, 1988). Why, then, did a university committed to educational equity apply the same entrance formula across the board? Data indicated that the University enrolled $30-40 \%$ of its Black student body through the category of "Special Admissions" (Apodaca \& Baratta, 1987, p. 6).

Special Admissions is decentrally administered on a campus-by-campus basis. The Special Admissions process, on the surface, seemed to signal an improved inclusionary posture. Yet with a little effort, analysis reveals how the University of California system as a whole has avoided the institutionalization of this affirmative action admit group. While the University of California system has allowed the campuses to admit up to 8 percent of incoming classes through Special Admissions, the UC system has not provided leadership to individual campuses on how to implement the Special Admissions process nor to whom it should be granted.

In some of the campuses, the slots for this admission category are split equally between the varsity coaches and the Educational Opportunity Programs. The 4\% remaining with these Educational Opportunity Programs must be shared among all lowincome applicants, regardless of ethnicity. By delegating responsibility to the individual campus and its faculty, the University as a system has attempted to avoid class action 
suits. Complaints have been sidestepped by citing local campus requirements for diversity. The question of parity itself reveals another dubious posture of the UC system.

Parity, according to the UC system, is based on reaching a quantitative ethnic representation equal to the California graduating high school class. If parity were based on age groups as opposed to high school graduates, the reality of the problem would be better understood. The truth is that the public educational system often loses at least $33 \%$ of the Black students before the senior year of high school, another $60 \%$ is "ineligible" or chooses not to apply for UC admission, and only about $1-2 \%$ will graduate with a bachelor degree from a UC campus (California Postsecondary Education Commission, 1985, December, p. 26).

On the other hand, if the UC system chooses, as it may in the future, to define parity in relation to the UC's category of "eligibility" (for Black students this was $3.4 \%$ of its high school graduating class in 1983), then equity policy success, by redefinition, will have been reached with Black students and they could then be removed from the Student Affirmative Action protected category of "underrepresented."

UC's preoccupation with increasing the "UC eligible" Black student pool, so as to (1) avoid the responsibility of providing college preparatory (or developmental) skills commonly called remediation, and (2) to appear impartial in the eyes of the other populations applying for admission to the UC system, is another apparent example of what has been recognized as UC's ambivalence. UC Berkeley is an exception on this point as shown through its Professional Development Program, in which adaptation skills are provided. However, this exception only highlights the rule of neglect and "victim blaming" done by the UC as a system and the HWCUs in general.

The characterization of this underrepresentation as an "eligibility problem," has caused the problem to be interpreted as a "lack of adequate preparation" on the part of Black students instead of the problem being seen as a lack of preparation on the part of 
the University (a public university at that) to meet the needs of the public which it is obligated to serve. This mistake was compounded by the UC system's sluggish posture in making a positive public statement on its policy toward the admission of Black students who did not fall into its eligibility category. The bravery of an outright invitation to those previously undereducated students showing academic promise would surely have increased the attractiveness of the UC system to a growing number of Black students. However, this should not be expected as long as the watchwords for the UC system continue to be "increase Black student eligibility" for admission.

In January, 1986, the president of the UC system, David Gardner, established the Task Force on Black Student Eligibility (hereafter referred to as the Task Force). The Task Force was to address the issue of the low rates of Black high school graduates eligible for $\mathrm{UC}$ admission.

The low rate of black students' eligibility for admission to higher education has generally been understood as a problem of poor school performance and underachievement at the K-12 level. What happens in schools, however, represents only one set of issues among a variety of factors that affect eligibility. The cognitive and communicative competence of black students (particularly those that come from low income families), their pre-school socialization, their perception of life chances beyond schooling, their self-esteem, their parents' and their own orientations toward schooling, as well as the issue of effective schooling itself, (including the cultural orientation of the school and the social and material resources of the schools that serve black youth) are all prominent among these factors. Moreover these factors tend to operate on more than one level, and have significant interactive effects. In order to formulate effective intervention strategies for enhancing black student eligibility, it is essential to recognize both the multiplicity of factors and their interrelationships. (Underwood, 1988, p. 14).

The Task Force's review of the literature goes on to point out the role of racism within society and the obstacles it places in the path of Black student eligibility. According to the review these obstacles take the form of school systems that use a monocultural approach in both educational content and methodology. Attitudes of prejudice as well as self-fulfilling predictions of failure and underachievement plague 
Black children from their earliest experience within the public educational system. While the review reminds us that there is a middle-income group of Blacks that are able to avoid these dilemmas, most of the Black population face these real problems. This downtrodden group is growing much faster than the middle-income group and makes up a considerable portion of California's inner cities.

The need for the University of California system to serve this population is clear yet the commitment for it to do so is not. The UC system has expressed concern over the pressure coming from Asian and White populations that are complaining about being denied admissions while students with lower eligibility indexes are admitted because they are underrepresented.

In a UC FOCUS, September 1987 issue, an article titled "California's Master Plan for Higher Education: Struggling to make a good document better" by Michael Lassiter, UC Regent Frazier stated:

On our Berkeley and Los Angeles campuses the percentage of blacks and Hispanics in the freshman classes is approximately the same as those among graduating high school seniors.... In fact, the increased representation of these groups is one of the causes of the increasing enrollment pressures on the University. You are asking us to maintain these gains in the face of public pressure which will result from limiting the access of other groups (Asians and whites) to our freshman class. (p. 8)

One would think that a center of intellectuals, like the UC system, would be able to define the historic, social, political, economic and moral imperatives of programs that would guarantee the meeting of educational needs for all elements of society. Here, again, the UC system is underprepared to educate the public on this issue and unable (ineligible) to educate itself. This becomes apparent when one observes the UC system as it asks the wrong questions and uses false categorization. The victim's eligibility is the wrong question and the grouping of all "non-traditional" students into the category of "minority" is categorical absurdity. The question must be raised as to whether the grouping of various non-European descended groups is not an opportunistic response 
emerging from political pressures that the UC system is not philosophically nor ideologically able to comprehend.

Kolb (1988, February) exposes the sleight of hand used by the UC system as it describes its alleged success with affirmatve action programs:

Affirmative action programs are starting to pay dividends; recruitment of underrepresented minority students has resulted in an average eight percent increase in new enrollments of those groups for each of the last seven years; the 10,700 black and Chicano undergraduates enrolled in 1986 was 9.7 percent of the total domestic student enrollment for the year. (p. 8).

Further research reveals that combining these two groups, Blacks and Chicanos, actually hides the stagnating status of new Black enrollment. Figures for Black incoming undergraduate students for 1980 and 1990 were $3.9 \%$ and $4.4 \%$ of the total incoming undergraduate students, respectively; the Chicano proportion of these incoming classes was $4.4 \%$ and $7.9 \%$, respectively; the Latino proportion changed from $1.8 \%$ to $4.1 \%$ (University of California Admissions and Outreach Services, 1987, September, p. 2; University of California Admissions and Outreach Services, 1991, Fall, p. 3) . Its clear that the affirmative action programs have not helped all groups equally.

A disturbing aspect of the Task Force report is that it speaks of no provisions to be made in the admissions process to factor in problems which are beyond the student's control. While many of the considerations mentioned in the report are valid, they still focus solely on the student's inability (ineligibility) to be like those who come from "traditional backgrounds." The report went on to state:

The historical and social conditions that have shaped the structure of American society have significantly restricted the social mobility of a large proportion of the black population. A dual system of social status, in which birth-ascribed status is reckoned along with achieved status, has emerged. Discriminatory practices in a range of institutional domains -- from housing and employment to education -- have profoundly affected the structure of opportunity in American society. These practices have systematically excluded large numbers of black people from valued positions and placed severe limits on their ability to achieve economic security.... 
We cannot avoid the conclusion that black student achievement poses larger social, economic, and educational issues. Eligibility for university admission is not simply a matter of what black students can or cannot do in school. It is more conclusively a question of what they are motivated and willing to do, given their cultural values and their status as members of a politically and economically marginal minority group.... It is the task of those who would increase the eligibility rate among black students to assess the combination of those factors which are open to administrative action and address them through comprehensive policy initiatives. (Underwood, 1988, pp. 2-5)

Here we must pause and take inventory of the reflective language of the report. It refers to the myriad factors affecting this "marginal group." This designation of marginality evolves from a vantage point that considers the Black student as being on the outside trying to get in. It appears here that the attitude of cultural superiority has again obscured the issue of institutional responsibility of the UC system. This is the frustrating aspect of the report. It comes close to the mark but continues to miss it.

When the report does hit the mark, as revealed in the following passage, it resigns the UC system to a position of defeat and/or irresponsibility:

Given the multilevel pervasiveness of the school and university factors affecting black student achievement, efforts to remedy them clearly cannot be limited to programs that affect individual students or any one level of their school experience. A broader approach, encompassing the whole social institution of the school or university and its community and societal context, is needed. If teachers, students, and parents are ambivalent, and even profoundly alienated, from the school and what it represents, it is largely due to the experience of the school as an institution that symbolizes their sense of powerlessness in the face of the social constraints they confront. Yet many of those constraints may be unavoidable aspects of an overly rigid school structure. This is not to say that schools should be totally egalitarian in structure. In fact, many scholars have emphasized the importance of the principal's role in providing firm direction for the carrying out of school policies. At the same time, however, that direction needs to be aimed at eliminating the sense of powerlessness that black students and parents experience. It needs to be aimed at providing black students with a confident sense of responsibility for their educational experience. [What of the responsibility of the HWCU?] Toward this end, the full range of their experience outside school needs to be acknowledged and valued as an integral part of their learning experience in school. (Underwood, 1988, p. 39) 
This excerpt raises some questions. The first is the assumption that the "constraints of an overly rigid school structure" are unavoidable. If "constraints" are the problem then they should be the focus of the solution. In the interim, the victim needs to be assisted, not blamed. Secondly, the report suggests that "the full range of their experience outside school needs to be acknowledged and valued as an integral part of their learning experience in school." Does this statement argue for an adjustable or amendable admissions criteria, and if so why is this not stated?

Another problem of the Task Force report is the trivialization contained in the phrase, "the sense of powerlessness that black students and parents experience." Here the actual powerlessness experienced by the Black community is reduced to a "sense," a feeling.

Even if one feels that the literature review done by the Task Force exhaustively explains the problems of "Black ineligibility," the application of "the eligibility argument" is itself an error. Critics of special admissions programs see the eligibility formula as an objective tool for measuring potential success and admissibility. However, when the formula works in the interest of a non-White ethnic group, the response from at least one of the UC campuses was questionable. The declared impartiality and objectivity of the eligibility formula was put under scrutiny when the treatment of the most "eligible" portion of California's population, Asian students, was examined. According to Kolb (1988, February), White students gained admissions to UC Berkeley at a generally higher rate than Asians though these Asian students have a higher eligibility rate. So much for eligibility!

There are some, however, who say that eligibility is not the real problem facing Black youth. They argue that since college entrance test scores, grade point averages, and high school graduations have increased among the Black population since 1980, student eligibility was not the real problem causing low Black enrollment (Ferris, 1979; 
Stikes, 1984; Anderson, 1988). According to Sudarkasa (1988), total enrollment of Blacks in higher education from 1976 to 1984 declined from $9.4 \%$ of the total college population to $8.8 \%$ with the proportion of Black high school graduates attending college dropping from $33.5 \%$ to $26.1 \%$ (p. 10 ). Here we can see that although the graduation rate of Black high school students increased by $8.1 \%$ from 1976 - 1985 (p. 10) the enrollment rate of this group has not kept pace.

Lack of preparation of the HWCUs in general, and the UC system in particular, is the real problem causing declining enrollment of Black students (Hall \& Young, 1979; Stikes, 1984; Anderson, 1988). Because of federal desegregation legislation and state affirmative action legislation, these institutions are currently obligated to enroll the majority of Black college students. This is a task that requires a new outlook on education that was not required with the traditional student body attending these institutions or with the homogeneous complement that came in with the GI Bill. It is a task that requires reorganization of resources (Ferris, 1979). It is a task that requires the intellectual training needed for a diverse environment (Stikes, 1984; Anderson, 1988). In order to qualify themselves (become eligible) to achieve this task, the HWCUs must begin with themselves.

HWCUs cannot continue to blame the public K-12 system without intervening on the part of the victimized underserved students that they admit. HWCUs should not wash their hands of those members of the public who are at the bottom of the socio-economic scale because of the elite attitude of the faculty. Because it is a public institution claiming to serve the California public, the University of California must make profound changes. This task requires proper preparation.

The first part of that preparation is the construction of a healthy image. A campus that wants to recruit students must understand the sales part of recruitment. All successful business endeavors require the establishment of a healthy image. This means 
that the image of the product to be purchased is a good one. It means that the product has credibility, attractiveness, and utility for the prospective customers. If the product is foreign to the consumers then potential customers will ignore its potential value. If the product is hostile, then the customer will avoid it. The University of California's educational offerings are both foreign and hostile according to Black students at the University of California, Irvine. This statement made by the African American Students Union, November, 1990, at UC Irvine, is revealing:

Despite popular opinion the University of California is still a segregated institution. We the African American Students Union of the University of California, Irvine think that this "Students of Color" conference needs to address itself to this outstanding fact. The current figures for African American enrollment are. . 2-3\% system wide, the percentage of faculty in the University of California mirror the national statistics, at about 2-3\%. In 1960 the national figures were the same. The current figures are unchanged after 30 years of so-called affirmative action!!

This scenario is paralleled in other oppressed people. ... This scenario is made worse by the fact that the majority $(60 \%)$ of African American faculty are at historically black institutions, so that underrepresentation in places like the University of California, are actually understated. Added to that is the absence of a curriculum that addresses the issues of African Americans or any other nonEuropean derived people. ...

A redefinition of the problem emerged from the reactionaries in the Carter, Reagan, and Bush administrations. Rhetoric such as "reverse discrimination," and "differential treatment" replaced any real dialogue concerning the still fundamentally racist nature of the American opportunity system. (Statement of the African American Students Union for the Second Annual Students of Color Conference, University of California, Irvine. November 3-4, 1990, pp. 1-2; author's italics)

The faculty and administration are only a part of the overall environment which is foreign and hostile to the Black student. When it is stated that the UC campuses are foreign to the Black community this is not meant metaphorically or symbolically. It is a literal fact that there is not one UC campus located in a Black inner city. All of them are in suburban areas or in affluent White communities. Recent talk of building a new UC 
campus gives no hint to changing this trend! It is no wonder that research of and service to the Black community remains elusive or at a minimum. With this being the case, the faculty remains insensitive to the needs of "those people." The environment created by this faculty and their approved curriculum constitutes the hostile backdrop. That overt and covert racist interactions occur in this context should come as no surprise.

HWCUs, like the society which they mirror, are plagued with the negative ideological and attitudinal manifestations of racism (Pilgrim, 1985). While the university in general is supposed to provide all the information in the universe (Harris, 1990), this is not the case. The area of curriculum probably demonstrates the most intense contradiction of mindsets between the Black community and the HWCUs.

While many campuses speak of their effort to diversify, this effort is merely one of "coloration," for the actual cultural focus is still that of a Western type. The University of California system serves as a case in point. The Bachelor degrees offered in Western cultural topics are nine times more available than those offered in African cultural topics. As a matter of fact, only four campuses offer a Bachelor degree in African related topics. At the Masters degree level, only one campus offers an African cultural topic and there are no such offerings at the Ph.D level on any campus (see Table 2).

The degrees offered by a campus usually signify the values and priorities of departments, the senior faculty of those departments and curriculum committees. The quality and type of degrees offered, along with the level of difficulty to be mastered, determine the focus of the "universal" courses offered. UC's superficial presentation of African cultural curricular topics suggests that UC's presentation in curricular areas of History, Social Science, Sociology, Political Science, Philosophy, and Psychology, in fact, neglects a Black perspective appropriate to a curriculum serving California's multicultural population. The faculty diversity and cross-cultural curricular expertise is 
Table 2

Comparison of Cultural Degree Offerings Within the University of California

\begin{tabular}{|c|c|c|c|}
\hline \multirow[b]{2}{*}{ Majors } & \multicolumn{3}{|c|}{ Degree Types Offered } \\
\hline & Bachelor & Masters & Ph.D. \\
\hline Black Studies $^{\text {a }}$ & 4 & 1 & 0 \\
\hline $\begin{array}{c}\text { Non-Western } \\
\text { Studies }^{b}\end{array}$ & 26 & 6 & 3 \\
\hline Western Studies ${ }^{c}$ & 38 & 29 & 28 \\
\hline $\begin{array}{l}\text { Universal Topical } \\
\text { Studies d }\end{array}$ & 43 & 33 & 39 \\
\hline
\end{tabular}

Note. Data taken from 1989 - 90 and 1990 - 91 UC campus catelogs. ${ }^{a}$ Afro-American Studies, African Area Studies, and African Language Studies. bAsian (Chinese Studies, East Asian Studies, Near East Asian Studies), Chicano, Latin American Studies, Women's Studies and Native American Studies. 'English, French, German, Italian, Greek, Spanish, and Portuguese Studies. dSocial sciences that profess teaching universal perspective and include: World History, Social Science, Sociology, Political Science, Philosophy, and Psychology.

obviously lacking. This gap in understanding different cultures becomes wider in the presentation of the culturally deficient curriculum provided by the HWCUs. The following statement by the President of Stillman College, (Wynn, 1990) is revealing.

A few weeks ago, I reviewed some unpublished research data, ... [that] revealed that students from a diverse sampling of primary, elementary, secondary, and postsecondary schools were unable to identify such prominent Black historical figures as Frederick Douglass, Harriet Tubman, Charles Drew, George Washington Carver, Crispus Attucks, Phillis Wheatley, Richard Allen, Booker T. Washington, W.E.B. DuBois, Benjamin Banneker, Rosa Parks, Mary McLeod Bethune, Ida B. 
Wells, James Weldon Johnson, Jesse Owens, and many others of equal renown. In reading this information, I was both suprised and dismayed that only 12 percent of the population surveyed was able to correctly identify the contributions of these notable African-Americans. From this experience, one can readily see that there is sufficient evidence to conclude that Black history is still trapped and needs a big dose of inclusiveness across the school curriculum. (p. 28)

Here, the Africentric and Eurocentric philosophy run into direct contradiction. The implicit historical mission of the HWCU was to rear its students in the manners, customs and laws of elite European cultural heroes. Since HWCUs originally catered exclusively to White students, complaints about this narrow view were readily beaten down. This ignorance was supported by the political, social, and economic postures required to build a world empire. This narrow world outlook was, and still is, the driving imperative of conquest.

Dr. W.E.B. DuBois (1976) noted the following:

Here for instance is a lovely British home, with green lawns, appropriate furnishings and a retinue of well-trained servants. Within is a young woman, well trained and well dressed, intelligent and high-minded. She is fingering the ivory keys of a grand piano and pondering the problem of her summer vacation, whether in Switzerland or among the Italian lakes; her family is not wealthy, but it has a sufficient "independent" income from investments to enjoy life without hard work. How far is such a person responsible for the crimes of colonialism?

It will in all probability not occur to her that she has any responsibility whatsoever, and that may well be true. Equally, it may be true that her income is the result of starvation, theft, and murder; that it involves ignorance, disease, and crime on the part of thousands; that the system which sustains the security, leisure, and comfort she enjoys is based on the suppression, exploitation, and slavery of the majority of mankind. (pp. 41-42)

The social paradigm constructed and reflected throughout the curriculum at HWCUs is that of a European civilization at the top of a hierarchical social structure and African savagery at the bottom of this structure. Logically, the affairs of a primitive human at best, or a subhuman at worst, required no serious study. This was the attitude of the HWCUs during the slavery and Jim Crow eras. It is common knowledge that 
attitudes tactically related to economic and political advantage/supremacy are continuously reinforced, some die hard and these attitudes have yet to die. These attitudes permeate the prevailing cultural posture of the HWCUs' faculty, administration and student body.

It does not take a college degree to realize that the HWCUs, in general, render little service to the Black community, directly or indirectly. When there is a cry for these "intellectual industrialists" to engage in service to the Black community it is usually spurred on and staffed by the Black Studies Departments and Programs, Black students, or minority programs working with "soft money." This attitude of marginality and neglect within HWCUs is reflected in the lack of resource commitment.

Successful programs to recruit, retain and graduate Black students cannot be built on a philosophical base that is individualistic, elitist, and racist. These values are problematic in the Black community as idea systems that mitigate against community self help and development.

According to Anderson (1989), there are key African behaviors, values, and beliefs that have been retained by American Blacks. Arguing against the assertion of total assimilation, Anderson attributes Blacks' retention of Africanisms to the Black church and family. He goes on to state, "a more significant explanation is that one's entire cultural style does not have to change because some behaviors are borrowed from the dominant culture" (p. 37).

Gyekye (1987) sums up African social thought as follows:

In African social thought human beings are regarded not as individuals but as groups of created beings inevitably and naturally interrelated and interdependent. This does not necessarily lead to the submerging of the initiative or personality of the individual, for after all the well-being and success of the group depend on the unique qualities of its individual members -- but individuals whose consciousness of their responsibility to the group is ever present because they identify themselves with the group. (p. 210) 
According to Anderson (1989), the difference of outlook, culture, and social values between the Black community and the HWCUs leads to skepticism on the part of the Black community. The Black community's skepticism is confirmed when one analyzes the baneful effects of the elitist, racist, and individualistic philosophical perspective within our class and caste divided society.

The HWCUs must come to understand the history and world outlook of the Black community in the context of the quest for higher education. Only then can the HWCUs appear as an attractive option for Black students. This understanding could transform both the HWCUs' approach and response to the essence of the Brown v. the Board of Education (1954) adjudication because it would provide the rationale based on justice and the enlightenment that most universities claim to seek. The logic of this statement is that the absence of the history and world outlook of the Black community decreases the ability to obtain enlightenment; thus, this history and worldview is required for the mission of these universities.

Then, of course, the expenditure of resources for institutionalized programs (in other words, commitment) could arise from conviction. The longer it takes for American higher education to provide this commitment, the more expensive it will be for American society which, in the long run, will have to pay the cost for a significant portion of its population, forced through circumstance, to live off of various forms of welfare. 


\section{RECOMMENDATIONS}

The problem of Black student access to American Higher Education is a complex one and it is made more complex by the reluctance of higher educational institutions to do a self assessment of their multiculturality -- or lack thereof. The author of this thesis recognizes the importance of gauging the preparedness of potential incoming students. However, the preparedness of institutions of higher education should also be assessed by the colleges and universities seeking to educate ethnically diverse populations.

Recommendations of the Task Force on Black Student Eligibility (1990), representing the University of California system, are listed below and are followed by a set of recommendations from Dr. J. A. Anderson, Associate Professor of Psychology, Indiana University of Pennsylvania. Finally, a list of synthesized recommendations is made by the author of this thesis, addressing the preparedness of colleges and universities to gain access to Black students.

\section{UNIVERSITY-BASED INITIATIVES AND PROGRAMS:}

1. Improve the coordination and effectiveness of all University of California precollege programs to expand the pool of eligible African American students. [1.1] Promote the effectiveness of the full range of University-sponsored precollege programs and improve inter-program coordination.

[1.2] Organize, encourage and reward University faculty for participation with $\mathrm{K}$ 12 faculty in new and existing academic programs that enhance African American achievement at all educational levels.

[1.3] Establish a University of California mentoring program designed to work towards improving the self-esteem and academic achievement of educationally "atrisk" junior high and high school students.

[1.4] Expand UC Early Outreach to serve $100 \%$ of the schools with a significant number of African American students within the next three to five years.

[1.5] Move decisively to assure that outreach and other affirmative action efforts are accorded high priority by the University's central administration as well as by the respective UC campus central administrations.

[1.6] Conduct both long-term and short term research on the University's ongoing outreach efforts. 


\section{COMMUNITY COLLEGE TRANSFER PROGRAMS}

2. Provide greater support for existing initiatives and special programs designed to increase the proportion of African American students who transfer from the community colleges to the University of California.

[2.1] Expand existing programs and develop new initiatives for counseling and preparing African American community college students for transfer to the University of California.

[2.2] Intensify and expand collaborative efforts with California community colleges to facilitate the transfer process for African American community college students.

\section{FACULTY RECRUITMENT HIRING}

\section{Recruit and hire more African American faculty.}

\section{SCHOOLS OF EDUCATION}

4. Ensure that the University's schools of education are oriented toward the state's increasingly multicultural classrooms, and produce well-trained teachers and administrators thoroughly informed about the varied educational needs of African American students, firmly committed to answering those needs, and highly skilled in providing effective instruction.

[4.1] Institutionalize and give high priority to pre-service and in-service programs and projects that address cultural, ethnic, and linguistic diversity.

[4.2] Increase efforts to recruit and graduate African American students interested in and committed to careers as $\mathrm{K}-12$ teachers, pupil personnel and administrators. [4.3] Expand transfer programs with community colleges and encourage transfer students to pursue careers in education.

[4.4] Increase collaborative efforts with school districts to improve instruction by developing in-service programs that will enhance the education of African American students.

[4.5] Promote the establishment of "Future Teacher Clubs" at the secondary and postsecondary levels.

[4.6] Establish special scholarship, fellowship and loan forgiveness programs to encourage African Americans to pursue teaching careers.

\section{RESEARCH AND INFORMATION DISSEMINATION}

5. Establish a multi-campus research unit (MRU) to conduct further research and disseminate information on issues relating to the African American experience, particularly academic achievement and eligibility for higher education. 
[5.1] Sponsor long-term and short-term research on the problems associated with the academic achievement and university eligibility of African American students. [5.2] Sponsor seminars, workshops, conferences, and hearings on issues related to African American student achievement and university eligibility.

[5.3] Monitor the University's implementation of the Task Force's recommendations regarding African American eligibility.

[5.4] In collaboration with indigenous community leadership, establish University of California Educational Services Field Stations in several cachement[sic] areas with high density of African Americans.

\section{UNIVERSITY COLLABORATIVE EFFORTS AND LINKAGES SCHOOL IMPROVEMENT COLLABORATIONS}

6. Take the lead in the development of school-improvement collaborations in order to provide academic interventions, beginning in the early elementary grades and extending into all levels of $\mathrm{K}-12$, in schools with high percentages of educationally "at risk" or disadvantaged African American students.

[6.1] Established at least two model schools, on a pilot basis, designed to increase the general pace of learning for educationally "at-risk" or disadvantaged African American elementary school students and thereby close the gap between them and their more advantaged peers.

\section{COMMUNITY-BASED PROGRAMS}

7. Create a mechanism to support independent community-based programs designed to improve the academic performance of African American children. [7.1] Encourage the campuses to establish formal links with community-based academic support programs for African Americans whereby the University's considerable technical expertise, academic facilities, and human resources might be made available to such groups.

[7.2] Take a more active role in seeking out faculty, students, staff and administrators, and in providing them with service credit, for assisting communitybased academic support programs for African American youth.

[7.3] Take a leadership role in encouraging private corporations and foundations to provide financial support for community-based academic support programs for African Americans.

[7.4] Devise a program to provide community-based academic support programs with advice and guidance on government, corporate and foundation fund raising. 


\section{COMMUNITY DEVELOPMENT}

8. Establish a mechanism, in collaboration with private industries and corporations and with state and federal agencies, to support community development, particularly economic and health services development, in African American communities.

\section{STATE AND LOCAL AGENCIES}

9. Collaborate with the State Department of Education, the Commission on Teacher Credentialing, and other state and local educational agencies to improve teacher preparation and to advance the development of a curriculum sensitive to student diversity at both the K-12 and postsecondary levels.

[9.1] Ensure that the standards on multicultural education established by the Commission on Teacher Credentialing (CTC) are being met by the University's schools and departments of education.

[9.2] Provide leadership in making sure that the K-12 and undergraduate curricula reflect the culturally and ethnically diverse history of the state and nation, so that all students develop a knowledge of the place of African Americans, as well as the place of other ethnic groups, in history.

[9.3] Vigorously promote the elimination of tracking systems that cut off higher education options and serve as disincentives for many African American youth.

[9.4] Promote the expansion of precollege guidance efforts which coordinated with $\mathrm{K}-12$ schools and beginning at the early elementary school level, provide precollege African American students with appropriate academic diagnostic assessment, as well as academic enrichment services.

\section{LEGISLATIVE INITIATIVES}

10. Sponsor and promote legislation and other initiatives calling for a statesupported scholarship program that would supplement other educational assistance programs and provide comprehensive financial and out-of-school academic support as incentives for educationally "at-risk" African American students to attend college.

[10.1] Take the lead, together with the State Department of Education, in more effectively disseminating information about Cal Grant and other grant programs to African American students and their families.

[10.2] Participate with the State in formulating legislation to develop a scholarship program designed to cover the difference between the amount of grants and loans for which poor students might qualify and the actual financial responsibilities of the individual. 
[10.3] Sponsor or support state legislation to make funds available to communitybased educational support programs in collaboration with University of California campuses. (pp. 12-16)

Anderson (1988) recommended the following for educational institutions that

worked with multicultural students:

At the superficial level, cross-racial, cross-ethnic teaching, learning, and/or service delivery occurs when the persons interacting are of different racial or ethnic identities. When one adds to this equation the differences in degree of acculiuration and type of cognitive/learning style, the examination and explanation of these differences becomes more complicated and the urgency to identify the critical dimensions associated with them more pronounced. Whereas it was once fashionable and sometimes academically rewarding to deny the existence of cultural assets and variations among non-white populations, social scientists and researchers now recognize that such traditional approaches have become anachronistic. The failure of retention programs, the ineffectiveness of service delivery to multiethnic populations, and the inability to produce effective communication between majority and minority members are glaring examples that new models and approaches must evolve which not only deal with debilitating misconceptions about minorities, but, more important, also operate within a framework of equal respect and appreciation for the similarities and differences among groups. ...

A different set of understandings about the way diverse populations communicate, behave, and think needs to be developed by educators. Until this occurs, educators will continue to stagnate in the dark ages and educators will provide lip service rather than action to the egalitarian values associated with pluralism and multiculturalism. Minority researchers have begun to affirm the value and viability of their cultural strengths and will expect institutions to reciprocate. As professional educators, we must settle for nothing less. (pp. 50-51)

The following are the author's recommendation for improving Black student access to American Higher Education in general and the University of California in particular:

1. Build campuses in the inner cities where there are high concentrations of Black students. Hire, where possible, from this community. Provide services that are unique to a college or university (well equipped libraries, meeting places, and special educational and entertainment events of interest) to the community. This action would rapidly increase the visibility of the institution in the Black community. 
If one observes the demographics of the California State University campuses it would be clear that those campuses near or in Black communities have a higher percentage of Black students than those campuses outside of these areas. The University of California, however, does not yet have a campus similarly placed.

2. Adopt high schools and community colleges where the majority of the student population is Black. Provide in-service training to teacher and counseling staffs. Encourage student tutorial programs and hot-lines for homework support especially in the math and science areas. Provide economic and mentoring support for high school and community college Black Student Unions. Organize concurrent enrollment agreements with adopted community colleges. Have professors from the university or college teach for one semester or quarter per five year period in the adopted high school or community college.

The implementation of this recommendation would reflect a responsible awareness on the part of the University of California system that it is the titular leadership of public education in California. What the K-12 and community college systems lack must be supplemented by the University of California system. When this is done, the student that suffers from the deficiencies of these preparatory systems will not have to be the sole one responsible but will share responsibility with the public educational system as a whole.

3. Retrain university and college tenured faculty every five years to the needs and values of the Black and minority populations.

Faculty, who are the prime service providers and educators, must also be prepared to serve the populations that seek enrollment. This recommendation will ensure that the faculty is periodically briefed on pedagogical and ontological issues that face a student population that is in constant flux.

4. Adopt a Black church in the Black community and serve as a resource to it by offering the facilities of the campus for special events. 
Of all community groups and organizations the Black church has the potential to be the campuses' best recruitment support apparatus. The church in the Black community is the most able family oriented organization available to provide college counseling.

5. Institutionalize an objective tenure appeal process.

The success of these recommendations requires a process in place to negotiate the lingering racism. Without this process there is no guarantee that the campuses will move to reflect the demographics of society because academic departments tend to clone themselves and avoid diversity. 
References

Abdul-Khabir, T. (1986). Coalescing to make the university experience meaningful to black people: A history of the University of Akron's Black Cultural Center. In J. C. Elam \& A. H. Taylor (Eds.), Setting the tone for future trends (pp. 215-228).

Chicago: National Association for Equal Opportunity in Higher Education, Follett Press.

Abrams, R. (1989). U.S. Military and higher education. The Annals of the American Academy of Political and Social Science, 502, 15-28.

Anderson, J. A. (1989). Cognitive styles and multicultural populations. In J. N. Niba \& R. Norman (Eds.), Recruitment and retention of black students in higher education (pp. 29-54). Lanham, New York, London: National Association for Equal Opportunity in Higher Education, University Press of America.

Anderson, T. (1988). Black encounter of racism and elitism in white academe: A critique of the system. Journal of Black Studies, 18(3), 259 - 272.

Allen, W. R. (1988). The education of black students on white college campuses: What quality the experience? In M. T. Nettles (Ed.) Toward Black Undergraduate Student Equality in American Higher Education (pp. 57 - 85). New York; Westport, Connecticut; London: Greenwood Press.

Apodaca, E. C., \& Baratta, F. S. (1987). Persistence and graduation rates for regularly admitted and special action freshmen 1979-84. Office of the President: University of California, Admissions and Outreach Services

Associated Press. (1989). Racial incidents continue at Brown University. Black Issues In Higher Education, 6(19), 24.

Bass, N. (1980). Essay on the treatment and management of slaves. In J. O. Breeden (Ed.), Advice among masters (pp. 11-16). Westport, Connecticut; London, England: Greenwood Press.

Bennett, L. Jr. (1969). Before the Mayflower: A history of the negro in America. Baltimore, Maryland: Penguin Books. 
Bolden, S. H. (1986). Historically black colleges: Developing linkages for survival. In J. C. Elam \& A. H. Taylor (Eds.), Setting the tone for future trends (pp. 81-91). Chicago: National Association for Equal Opportunity in Higher Education, Follett Press.

Brown, C. G. (1988). The role and responsibility of the federal government: Strategies for achieving qualitative equality at the national level. In N. T. Nettles (Ed.), Toward Black undergraduate student equality in American higher education. (pp. 125-148). New York, Westport, Connecticut, London: Greenwood Press.

Cabral, A. (1973). Return to the source: selected speeches by Amilcar Cabral. Africa Information Service (Ed.). New York and London: Monthly Review Press.

California Postsecondary Educational Commission (1985, December). Director's report: From ninth grade through college graduation, who makes it in California education. (Available at the California Postsecondary Educational Commission, 1020 Twelfth Street, Sacramento, California 95814.)

California Postsecondary Educational Commission (1985). Eligibility of California's 1983 high school graduates for admission to the state's public universities: a report from the 1983 high school eligibility study. (Report No. 85-23). (Available at the California Postsecondary Educational Commission, 1020 Twelfth Street, Sacramento, California 95814.)

Carnegie Foundation for the Advancement of Teaching (December 1977). Missions of the college curriculum: A contemporary review with suggestions [Summary]. In The Carnegie Council on Policy Studies in Higher Education (Ed.), The Carnegie Council on Policy Studies In Higher Education: A summary of reports and recommendations (pp. 131-141). San Francisco, Washington, London: Jossey-Bass Publishers.

Carter, G. F. (1989). Financial aid and tuition: Factors contributing to the decline of black student enrollment in higher education. In J. N. Niba \& R. Norman (Eds.), Recruitment and retention of black students in higher education (pp. 89-125). Lanham, New York, London: National Association for Equal Opportunity in Higher Education, University Press of America.

Conciatore, J. (1989). Independent schools offer education close to home and heart. Black Issues In Higher Education, 6(19), 1,12-13. 
Dejoie, C. M., (1986). Strategy to confront disenfranchisement of black Americans in predominantly white universities. In J. C. Elam \& A. H. Taylor (Eds.), Setting the tone for future trends (pp. 229-236). Chicago: Follett Press.

Devarics, C. (1988). Black colleges step up efforts to get top students. Black Issues In Higher Education, 2/15/88, 24.

Du Bois, W. E. B. (1970). Black reconstruction in America. New York: Atheneum.

Du Bois, W. E. B. (1976). The world and Africa. New York and London: International Press.

Ferris, V. K. (1979). Perspectives for higher education opportunity programmes. In K. Hall \& A. Young (Eds.), Education and the Black Experience. (pp. 87-101). Palo Alto, California: R \& E Research Associates.

Flemming, J. E., Gill, G. R., \& Swinton, D. H. (1978). The case for affirmative action. Washington D.C.: Howard University Press.

Freeman, R. B. (1976). Black elite: The new marke: for bighly educated black Americans. New York, St. Louis, San Francisco, Aukland, Bogata, Dusseldorf, Johannesburg, London, Madrid, Mexico, Montreal, New Delhi, Pananma, Paris, Sao Paulo, Singapore, Sydney, Tokyo, Toronto: McGraw Hill Book Company for the Carnegie Commission on Higher Education.

Gordon, A. H. (1971). Sketches of negro life and history in South Carolina. Columbia, South Carolina: University of South Carolina Press.

Gossett, T.F. (1972). Racism at the turn of the century. In C. Young (Ed.), Black experience: analysis \& synthesis (pp. 109-112). San Rafael, California: Leswing Press.

Guzman, J. P. (1969). Lynching. In A. D. Grimshaw (Ed.), Racial violence in the United States. Chicago: Adeline Publishing Company

Gyekye, K. (1987). An essay on African philosophical thought: the Akan conceptual scheme. New York, New Rochelle, Melbourne, and Sydney: Cambridge University Press.

Harris, N. (1990). Multicultural education in a changing world. Black Issues In Higher Education, 7(6), 19. 
Haycock, K., \& Navarro, S. (1988). Unfinished business: Fulfilling our children's promise: A report from the Achievement Council. Oakland, CA; Los Angeles: Achievement Council

Institute for the Study of Educational Policy, Howard University (1976). Equal educational opportunity for Blacks in U.S. Higher Education: an assessment. Washington D.C.: Howard University Press.

Katz, W. L. (Ed.). (1969). The Negro in Virginia. New York: Arno Press and the New York Times.

Kolb, R. (1988). Admissions: a stretch for the fairest process. UC Focus. (Available from Office of University Relations, 131 University Hall, Berkeley, California 94720.)

Lang, M. (1988). Black Student Retention Problem in Higher Educaiton: Some Introductory Perspectives. In Marvel Lang and Clinita A. Ford (Eds.), Black Student Retention in Higher Education (pp. 3 - 11). Springfield, Illinois: Charles C. Thomas.

Lassiter, M. (1987). California's Master Plan for Higher Education: struggling to make a good document better. UC Focus. (Available from Office of University Relations, 131 University Hall, Berkeley, California 94720.)

Manning, W. H. (1977). The pursuit of faimess in admissions to higher education [Summary]. In The Camegie Council on Policy Studies in Higher Education (Ed.), The Carnegie Council on Policy Studies In Higher Education: A summary of reports and recommendations (pp. 383-384). San Francisco, Washington, London: JosseyBass Publishers.

Mbiti, J. (1970). African religions and philosophies. Garden City, N.Y.: Doubleday

Nettles, M. T. (1988). Black and white students' performance and experiences at various types of universities. In N. T. Nettles (Ed.), Toward Black undergraduate student equality in American higher education. (pp. 35-56). New York, Westport, Connecticut, London: Greenwood Press.

Nettles, M. T. (1988). Factors related to black and white students' college performance. In N. T. Nettles (Ed.), Toward Black undergraduate student equality in American higher education. (pp. 17-34). New York, Westport, Connecticut, London: Greenwood Press. 
Nettles, M. T. (1988). Introduction: Contemporary barriers to black student equality in higher education. In N. T. Nettles (Ed.), Toward Black undergraduate student equality in American higher education. (pp. 1-16). New York, Westport, Connecticut, London: Greenwood Press.

Nobles, W. (1990). The infusion of African and African American content: A question of content and intent. In A. G. Hilliard III, L. Payton-Stewart \& O. Williams (Eds.) Infusion of African and African American content in the school curriculum: Proceedings of the First National Conference (pp. 5-26). Morristown, N.J.: Aaron Press.

Orum, A. M. (1972). Black students in protest: A study of the origins of the black student movement. Washington D.C.: American Sociological Association.

Pilgrim, D. (1985). Deception by stratagem. Indiana: Wyndham Hall Press.

Smith, D. N. (1974). Who rules the universities?: An essay in class analysis. New York, London: Monthly Review Press.

Statement of the African American Students Union. (November 3-4, 1990). Paper presented at the Second Annual Students of Color Conference, University of California, Irvine, pp. 1-2.

Stikes, C. S. (1984). Black students in higher education. IL: Southern Illinois University Press.

Sudarkasa, N. (1988). Black enrollment in higher education: the unfulfilled promise of equality. In J. Dewart (Ed.), The state of Black America 1988 (pp. 7-22). New York: National Urban League, Inc.

Swinton, D. (1989). The Economic Status of Black Americans. In J. Dewart (Ed.), The state of Black America 1989. (pp. 9-40). New York: National Urban League, Inc.

Task Force on Assembly Concurrent Resolution 83, (1986). Expanding educational equity in California's schools and colleges: Recommendation of the Intersegmental Policy Task Force on Assembly Concurrent Resolution 83 (Commission Report No. 86-4). Available from California Postsecondary Education Commission, 1020 Twelfth Street, Sacramento, CA.

Task Force on Black Student Eligibility, (1990). Making the future different: Report of the Task Force on Black Student Eligibility. Berkeley: University of California. 
Toure, A. S. (1976). Revolution - culture and Panafricanism. Conakry: Patrice Lumumba Printing Press.

Underwood, C. (1988). Making the future different: Black student eligibility: a review of the literature. Berkeley: University of California, Task Force on Black Student Eligibility. (Available from Office of the President, 359 University Hall, Berkeley, 94720.)

University of California Admissions and Outreach Services (1987, September). Information Digest. Berkeley: University of California, Office of the President. (Available from Office of the President, 359 University Hall, Berkeley, 94720.)

University of California Admissions and Outreach Services (1991, Fall). Information Digest. Berkeley: University of California, Office of the President. (Available from Office of the President, 359 University Hall, Berkeley, 94720.)

Wiley, E. 3rd. (1989). Scholars push for cultural diversity in curruculum. Black Issues In Higher Education, 6(19), 1,10.

Williams, H., (1987, Spring). Covert racism: Another manifestation.Third World And Native American Students, p. 7.

Willie, C. F. (1987). The future of school desegregation. In J. Dewart (Ed.), The state of Black America 1987 (pp. 38-57). New York: National Urban League, Inc.

Wilson, D. A. (1989). Consequential Controversies. The Annals of the American Academy of Political and Social Science, 502, 40-57.

Woodson, C.G. (1968). The education of the negro prior to 1861. New York: Arno Press and the New York Times.

Wynn, C. (1990). Black history still trapped: another month of celebration. Black Issues In Higher Education, 6(23), 28. 